\title{
Covid-19 Pandemi Döneminin Sağlık Çalışanlarının Tükenmişlik Düzeylerine Etkisi
}

\author{
Edibe Asuman ATÍLLA*
}

Aybike KARAKAYA **

Geliş Tarihi (Received): 01.09.2021 - Kabul Tarihi (Accepted): 23.11.2021

\section{$\ddot{O} \mathbf{z}$}

Sağlık çalışanları, ruhsal ve fiziksel enerjilerini yüksek düzeyde harcayarak sağlık hizmeti sunmaktadırlar. Özellikle Covid-19 pandemi süreci, sağlık sisteminde oluşturduğu kriz sebebiyle söz konusu sağlık çalışanlarının üzerinde ciddi bir tükenmişlik riski oluşturmaktadır. $\mathrm{Bu}$ sebeple çalışmamızda, sağlık çalışanlarının tükenmişlik düzeyleri incelenmiş olup, Covid-19 pandemi sürecinin bu tükenmişlik düzeyleri üzerine etkisini belirlemek amaçlanmıştır. Bu amaçla sağlık çalışanlarına anket yöntemi kullanılarak sorular sorulmuş olup, anket uygulaması Google Forms web sitesi üzerinden yapılmıştır. Oluşturulan anket formu, katılımcıların sosyo-demografik verilerini ve çalışma şartları ile ilgili verilerini toplayan 24 adet açık ve kapalı uçlu sorudan ve 22 soruluk Maslach Tükenmişlik ÖlçeğiSağlık Personeli (MTÖ-SP) formundan oluşmaktadır. Araştırmaya 352 sağlık çalışanı dâhil edilmiştir. Katılımcıların \%53,4'ü erkek, \%44,3'ü 26-35 yaș aralığında, \%73'ü evli, \%39,8'i lisans eğitimi aldığı belirlenmiştir. Araştırma sonuçlarına göre katılımcıların \%67,3 oranında düşük duygusal tükenmeye sahip oldukları belirlenmiştir. Katılımcıların \%71,9 oranında düşük düzeyde duyarsızlaşmaya sahip oldukları ve \%40,6 düşük düzeyde kişisel başarı azalma hissine sahip oldukları tespit edilmiştir. Yapılan çalışma sonucunda, sağlık çalışanlarının pandemi süreci içerisinde çalışma şartlarının düzenlenmesi, gelir durumlarında iyileştirmeler yapılması ve görev dağılımlarının eşit olması gibi önlemlerin alınmasının, tükenmişlik sendromunun önlenmesinde olumlu katkıda bulunacağı tespit edilmiştir.

Anahtar Kelimeler: Tükenmişlik, Sağlık Çalışanları, Pandemi

\section{Effect Of Covid-19 Pandemic Perıod On The Levels Of Exhaustion Of Health Workers}

\begin{abstract}
Health workers provide health care by spending a high level of their mental and physical energy. In particular, the Covid-19 pandemic process poses a serious risk of burnout for these health workers due to the crisis it poses in the health system. For this reason, the burnout levels of health workers were examined in our study and it was aimed to determine the impact of the Covid-19 pandemic process on these burnout levels. For this purpose, health workers were asked questions using the survey method and the survey application was made through the Google Forms website. The questionnaire consists of 24 open and closed-ended questions that collect socio-demographic data and working conditions of the participants and a 22-question Maslach Burnout Scale-Health Personnel (MTÖ-SP) form. 352 health workers were included in the study. It was determined that $53.4 \%$ of the participants were male, $44.3 \%$ were between the ages of 26 and 35, 73\% were married and 39.8\% were undergraduate. According to the results of the study, $67.3 \%$ of the participants had low emotional exhaustion. It was found that $71.9 \%$ of the participants had a low level of desensitization and a low level of personal achievement reduction of $40.6 \%$. As a result of the study, it was determined that taking measures such as regulating working conditions, making improvements in income situations and equal task distributions during the pandemic process of health workers will contribute positively to the prevention of burnout syndrome.
\end{abstract}

Keywords: Burnout, Health Workers, Pandemic

\footnotetext{
*Doç. Dr. ,Ankara Hacı Bayram Veli Üniversitesi, İktisadi Ve İdari Bilimler Fakültesi, Sağlık Yönetimi Bölümü, asuman.atilla@hbv.edu.tr, ORCID: 0000-0002-2823-9801

**Doktora Öğrencisi, Ankara Hacı Bayram Veli Üniversitesi, Lisansüstü Eğitim Enstitüsü, Sağlık Yönetimi Bölümü, aybike.karakaya@hbv.edu.tr, ORCID: 0000-0002-3016-9953
} 


\section{Giriş}

2019 yılının Aralık ayında, Çin'in Hubei eyaletinin Wuhan şehrinde ortaya çıkan ve hızla yayılan pnömomi salgını tüm dünyayı etkisi altına almıştır. Ortaya çıkan vakaların etiyolojisi bilinmemektedir. Şiddetli akut solunum yollarını etkileyen bu patojen, 2019 yeni corona virüs (2019-nCoV) olarak adlandırılmıştır. Bu patojenin neden olduğu hastalık ise, 2019-koronavirüs enfeksiyonu hastalığı (Covid-19) olarak literatüre geçmiştir (Ge, Yang , Xia, Fu, \& Zhang, 2020, s. 363)

Covid-19 pandemisinin başladığı 2019 Aralık ayından, 5 Ağustos 2021 tarihine kadar Dünya Sağlık Örgütü (World Health Organization [WHO]) verilerine göre Dünya genelinde 4.255.892 ölümde dâhil olmak üzere 200.174.883 doğrulanmış Covid19 vakası bildirilmiştir. 4 Ağustos 2021 tarihi $\quad$ itibariyle toplam 3.984.596.440 aşı dozu uygulanmıştır. Ülkemizde ise, Sağlık Bakanlığı verilerine göre 51.875 vefat sayısı da dâhil toplam 5.846.784 vaka sayısı bildirilmiştir (WHO, 2021; T.C. Sağlık Bakanlığı, 2021).

Türk Tabipler Birliği tarafından Haziran 2021 de yapılan çalışmada, Covid-19'a yakalandıktan sonra hayatını kaybeden sağlık çalışanı sayısı ise 17.000 'den fazladır. Uluslararası Af Örgütü tarafından 5 Mart 2021'de sunulan raporda en fazla sağlık çalışanı ölümü yaşanan ülkeler Meksika (2.500) ve ABD (3.500) olarak kayıtlara geçmiştir. Türkiye'de, Sağlık Bakanlığı verilerine göre Covid-19 pandemisi ile mücadelede doktorlar, hemşireler ve diğer yardımcı sağlık çalışanlarından oluşan yaklaşık 540.000 kişilik bir sağlık ordusu görev almaktadır. Türk Tabipler Birliğinin Haziran 2021 yılında sunmuş oldukları raporda salgının başından 31.05.2021 tarihine kadar Covıd-19 hastalığına bağlı olarak yaşamını yitirmiş 403 aktif sağlık çalışanının olduğu görülmektedir (Nesanır, Bahadır, Karcıoğlu, \& Korur Fincancı, 2021:5, T.C. Sağlık Bakanlığg1, 2021).

Covid-19 salgınından en çok etkilenen meslek gruplarından biri sağlık çalışanlarıdır. Salgın devam ettiği sürece hem kendilerinin hem de yakınlarının hastalığa yakalanma riskinin bulunması, sağlık çalışanlarının tükenmişlik yaşamalarına neden olabilmektedir (Yumru, 2020, s. 5). Tükenmişlik, bireyin strese bağlı olarak motivasyon kaybı yaşaması ile birlikte çalışma hayatında yerine getirmesi gereken sorumlulukları yerine getirememesi, psikolojik olarak işinden uzaklaşması olarak tanımlanabilir. Özellikle insan hayatının söz konusu olduğu sağlık sektöründe, sağlık çalışanlarının tükenmişlik riski en fazla olan grup olduğu bilinmektedir (Partlak Güneşen \& Üstün, 2010 s. 43; Kaçmaz, 2005 s. 29). 
Bireylerin daha verimli çalışabilmeleri, kendilerini fiziksel ve zihinsel olarak iyi hissetmelerine bağlıdır. Covid-19 pandemisinin ise sağlık çalışanları açısından ciddi riskler taşıdığı ve bu durumun sağlık çalışanlarının stres seviyelerini arttırdığı düşünülmektedir. $\mathrm{Bu}$ sebeple bu çalışmada, Covid-19 pandemisinin sağlık çalışanları üzerindeki tükenmişlik seviyesine etkisini belirlemek amaçlanmıştır. Bu amaçla, öncelikle literatür taraması yapılarak tükenmişlik kavramı, evreleri, Covid-19 pandemisinin tükenmişlik düzeyine etkisi ve tükenmişliğin sağlık çalışanları üzerine etkisi belirlenmeye çalışılmıştır.

\section{Literatür Taraması}

Tükenmişlik kavramı ilk olarak Amerika'da 1970'lerde, Herbert Freudenber'in ortaya attığı 'burnout' kavramı Türkçeye ‘tükenmişlik' olarak çevrilmiş ve yaygın olarak kullanılmaya başlanılmıştır. Tükenmişlik, Herbert Freudenber'in aşırı duygusal bireylerin kişilerarası ve işyeri stres faktörleri ile karşı karşıya geldiği için kendisinin ve diğer meslektaşlarının bağlılık ve motivasyon eksikliği yaşadığını ele aldığı yazı ile ortaya atılmıştır (Karadayı, 2020 s. 24; Mukherjee, Tennant \& Beresford, 2019 s. 52).

Tükenme, aşırı yüklenmiş hissetmek, duygusal ve fiziksel kaynaklardan yoksun olmak anlamına gelmektedir. Tükenmişlik sendromu ise, mesleki olarak insanlarla yoğun ilişkiler içerisinde olan bireylerde görülen üç ana boyuttan oluşan psikolojik bir sendromdur. Bunlar; duygusal tükenme, duyarsızlaşma (sinizm) ve kişisel başarı hissinin kaybı (yetersizlik) boyutlarıdır. Duygusal tükenme boyutu, enerji kaybı, zayıflama, yıpranma ve yorgunluğu ifade etmektedir. Duyarsızlaşma boyutu, ürün veya hizmet talep edenlere karşı olumsuz tutum ve davranışları, sinirlilik ve idealizmin kaybını ifade etmektedir. Başarı hissinin kaybı boyutu ise; yetenekte veya üretkenlikte azalma, moral düşüklüğü ve stres ile baş edememe anlamına gelmektedir. Bu çok boyutlu tükenmişlik modeli, sosyal bağlamda bireysel stres düzeyinin önemini vurgular ve benlik kavramını içerir (Maslach \& Leiter, 2016 s. 104).

Tükenme dört evre ile tanımlanmaktadır. $\mathrm{Bu}$ evreler tükenmeyi anlamayı kolaylaştırmaktadır. Ancak tükenme bir evreden diğerine geçen kesikli bir süreç değil, devam eden bir durumdur (Ergin, 1992 s. 145):

Birinci Evre-Şevk ve Coşku Evresi (Enthusiasm): Bu evrede yüksek bir umut etme hali, gerçek dışı mesleki beklentiler ve enerjide yükselme gözlenmektedir. Birey için mesleği ilk sirada gelir. 
İkinci Evre-Durağanlaşma Evresi (Stagnation): Bu evrede umutta azalma ve isteksizlik başlamaktadır. Birey mesleğini icra ederken karşısına çıkan güçlüklerden ve daha öncesinde göz yumduğu problemlerden giderek rahatsızlık duymaya başlamıştır.

Üçüncü Evre- Engellenme Evresi (Frustration): Bu evrede birey diğer kişilere destek olmak, yardım etmek için çalışmaya başlamış, ancak sistemi değiştirmenin olumsuzluklarla başa çıkmanın ne kadar zor olduğunu anlamıştır. Yoğun olarak engellenme hissiyatı yaşar. Bu noktada 3 seçenekten biri seçilmektedir. Bunlar; adaptif savunma (uyum sağlama) ve başa çıkma stratejilerini uygulama, maladaptif başa çıkma (uyum göstermeme) stratejileri ile tükenmişliği ilerletme, durumdan kendini çekme ve kaçınma söz konusudur.

Dördüncü Evre- Umursamazlık Evresi (Apathy): Bu evrede, duygusal kopuşlar, ağır inançsızlıklar ve umudunu tamamen kaybetme hali gözlenmektedir. Birey mesleğini ekonomi ve sosyal güvence için devam ettirmekte, mesleğinden zevk almamaktadır (Düzyürek \& Ünlüoğlu, 1992 s. 110; Fawzy, Fawzy, \& Pasnau , 1991 s. 119; Kaçmaz, 2005 s. 30). Covid-19 salgınının sağlık çalışanları üzerinde kalıcı bir psikolojik etkiye sahip olması ise beklenen bir durumdur.

Covid-19, çok kısa sürede tüm dünyaya yayılan; yüksek enfeksiyon ve ölüm oranıyla, stres, anksiyete, depresyon, korku ve tükenmişlik gibi birçok psikolojik soruna yol açan bir durumdur (Arslan, Yıldırım, Tanhan, Buluş, \& Allen , 2020 s. 3). Bu tür psikolojik sorunları önlemek için, Covid-19 salgını sırasında bireylerin stres ve tükenmişlik deneyimi ile ilişkili faktörleri anlamak önemlidir. Mevcut Covid-19 salgını sırasında, uluslararası sınırların ve eyalet sınırlarının kapatılması, şehir ve alan yasağının getirilmesi sağlık çalışanlarını ve ailelerini de etkileyerek olumsuz psikolojik durumlara sebep olmuştur. (Khasne, Dhakulkar, Mahajan \& Kulkarni, 2020 s. 666).

Lasalvia ve diğerlerinin (2020) Covid-19 salgını sırasında İtalya'nın kuzeydoğusunda üçüncü basamak bir hastanede görevli sağlık çalışanları üzerine yapmış oldukları çalışmada sağlık çalışanlarının tükenmişlik düzeyleri ve ilişkili faktörlerini belirlemeyi amaçlamıştır. Çalışmanın sonucunda Covid-19 hastalarıyla doğrudan ilgilenen sağlık çalışanlarının, Covid-19 olmayan servislerde çalışanlara göre daha fazla tükenmişlik yaşadığ görülmüştür. Son olarak, önceden psikolojik sorunları olan çalışanlarda, Covid-19 ile ilgili travmatik bir olay yaşayanlarda ve iş yeri ile kişisel yaşamda kişilerarası kaçınma yaşayanlarda tükenmişlik riskinin daha yüksek olduğu sonucuna ulaşılmıştır. Ayrıca Covid-19 salgınının sağlık çalışanları için büyük bir endişe kaynağı olduğu görülmüştür. Maunder ve diğerlerinin 
(2021) Covid-19 salgını sırasında yapmış oldukları çalışmada, zaman içinde duygusal tükenme ve psikolojik sıkıntıdaki değişikliklerle ilgili bireysel özelliklerin değerlendirilmesi amaçlamıştır. Sonuç olarak bu tükenmişlik durumunun çocuk sahibi olan sağlık çalışanlarında daha yüksek olduğu belirlenmiştir. Çalışma sağlık çalışanlarının psikolojik yükünün yüksek olduğu ve pandemi sürdükçe de artmaya devam edeceği belirtilmiştir.

Tükenmişlik, özellikle sağlık çalışanlarının fiziksel ve zihinsel refahını etkileyen, küresel olarak giderek artan bir endişe olarak kabul edilmektedir. Baptista ve diğerlerinin (2021) birinci basamak sağlık hizmetlerinde görev yapan hekimler üzerine Portekiz'de yapmış oldukları çalışmaya 214 hekim dâhil edilmiştir. Çalışmada üç farklı boyutta (kişisel, iş ve hasta ile ilgili) çalışanların tükenmişlik düzeyleri, dayanıklılık, stres, depresyon ve anksiyete durumları değerlendirilmiştir. Sonuç olarak hekimlerin 3 boyutta da tükenmişlik düzeylerinin yüksek olduğu görülmüştür. Cinsiyet, mesleki deneyim, depresyon, anksiyete ve tükenmişlik seviyeleri arasında güçlü bir ilişki olduğu da bildirilmiştir.

Sağlık çalışanlarının yaşayabilecekleri tükenmişlik, görev yaptıkları sağlık kurumları ve hastalar için olumsuz sonuçlara sebep olması nedeniyle de endişe yaratmaktadır. Shanafelt ve diğerleri (2010) tarafından yapılan bir diğer çalışmada, cerrahların tükenmişlik düzeyi ile tıbbi hatalar arasındaki ilişkinin belirlenmesi amaçlanmıştır. Sonuç olarak, cerrahlar tarafından bildirilen önemli hataların, cerrahın tükenmişlik derecesi ve zihinsel yaşam kalitesi ile güçlü bir şekilde ilişskili olduğu belirlenmiştir. Suñer ve diğerlerinin (2014) yapmış oldukları çalışmada ise, Latin Amerika ülkelerindeki sağlık çalışanları arasında tükenmişlik sendromunun sonuçlarını belirlemek, bunların tükenmişlik sendromu ve mesleki değişkenlerle ilişkisini değerlendirmek amaçlanmıştır. Sonuç olarak, duygusal tükenmenin, işe devamsızlık, mesleği bırakma niyeti, kişisel bozulma ve ailenin kötüleşmesi değişkenleri ile ilişkili olduğu belirlenmiştir. Tükenmişlik evrelerinden olan duyarsızlaşmanın ise en çok hata yapma değişkeniyle ilişkili olduğu sonucuna ulaşılmıştır.

Jalili ve diğerlerinin (2021) yapmış oldukları çalışmada ise Covid-19 hastaları ile ilgilenen sağlık çalışanları arasında tükenmişliğin yaygınlığı ve ilişkili faktörleri belirlemek amaçlanmıştır. Yapılan kesitsel araştırmada, üniversiteye bağlı altı hastanede Covid-19 hastalarına bakan sağlık çalışanları incelenmiştir. Yaş, cinsiyet, medeni durum, çocuk sahibi olma, hastane, iş kategorisi, deneyim ve iş yükü ile her bir alt ölçekteki tükenmişlik düzeyi ölçülmüştür. Sonuç olarak, Covid-19 hastalarına bakan sağlık çalışanları arasında tükenmişliğin yaygın olduğu belirlenmiştir. Ayrıca yaş, cinsiyet, iş kategorisi ve uygulama yerinin, tükenmişlik düzeyini etkilediği sonucuna da ulaşılmıştır. Pantenburg ve diğerlerinin (2016) 
çalışmasında, Alman doktorlar arasında tükenmişliğin ciddi oranda artmasının sebeplerinin belirlenmesi ve tükenmişlik ile Alman hekimlerin işten ayrılma istekleri arasında ilişkinin analizi amaçlanmıştır. Sonuç olarak, erkeklerin kadınlardan daha fazla duyarsızlaşma sergilediği görülmüştür. Katılımcıların \%11'i yüksek derecede tükenmişlik göstermiştir.

Bir diğer çalışma Leskovic ve diğerleri (2020) tarafından Slovenya'da huzurevlerinde görev yapan sağlık çalışanları ile gerçekleştirilmiştir. Çalışmada Covid-19 sırasında kırsal alanlarda ki bakım evlerinde görev yapan sağlık çalışanlarının iş tatmini ve tükenmişlik düzeyleri analiz edilmiştir. Çalışmada Covid-19 pandemi süreci hizmet sonuçları ile 2013 yılında aynı hizmetlerin sonuçları arasında bir karşılaştırma yapılmıştır. Sonuç olarak 20132020 yılları arasında tükenmişlik düzeylerinde artış belirlenmiştir. Katılımcılar, Covid-19 salgını sırasında yoğun bir duygusal tükenme ve kişisel başarı eksikliği yaşadıklarını belirtmişlerdir. Covid-19 salgınının, Slovenya'nın kırsal bölgelerindeki huzurevlerinde sağlık çalışanlarının hâlihazırda var olan tükenmişlik düzeylerini önemli ölçüde arttırdığı belirlenmiştir.

Covid-19 küresel salgını, yaşama ve çalışma tarzını büyük ölçüde değiştirmiştir. Uzayan salgının ortasında, ön saflardaki sağlık uzmanlarının tükenmişliği önemli bir endişe haline gelmiştir. Bu doğrultuda Nishimura ve diğerleri (2021) Japonya'daki sağlık uzmanlarında Covid-19 salgını ile tükenmişliğin yaygınlığı arasındaki ilişki hakkında veri sağlamak amacıyla kesitsel bir çalışma yapmışlardır. Sonuç olarak, sağlık çalışanlarının tükenmişliği, salgının ortasında, sürdürülebilir sağlık hizmeti sunumu için ele alınması gereken önemli bir endişe kaynağı olarak belirlenmiştir. Benzer bir çalışma da Alsulimani ve diğerleri (2021) tarafından Covid-19 salgını sırasında Suudi Arabistan'daki sağlık çalışanları arasında tükenmişlik yaygınlığını tahmin etmek ve bu popülasyonda tükenmişlikle ilişkili bireysel ve işle ilgili faktörleri araştırmak amacıyla yapılmıştır. Toplam 646 sağlık çalışanının dâhil edildiği çalışmada sağlık sektörü çalışanları arasında tükenmişlik yaygınlığının \%75 olduğu sonucuna ulaşılmıştır. Tükenmişlikle ilişkili önemli faktörler; yaş, unvan, hizmet yılı, salgın sırasında artan çalışma saatleri, günlük ortalama uyku saatleri, Covid-19 hastalarına maruz kalma, Covid-19 için test edilenlerin sayısı olarak belirlenmiştir. Araştırma sonucunda pandemi sırasında sağlık çalışanlarının psikolojik dayanıklılığını arttırmak için teşvik edilmelerinin gerekliliği ortaya konulmuştur. 


\section{Araştırma Metodolojisi}

Bu bölümde araştırmanın amacı, önemi ve hipotezleri açıklanmış ve araştırmada izlenen yöntemlere değinilmiştir. Evren ve örnekleme ilişkin bilgiler verilmiş, veri toplama araçları tanıtılmış ve veri analiz tekniklerine ilişkin açıklamalara yer verilmiştir.

\subsection{Araştırma Amacı ve Önemi}

Sağlık çalışanlarının pandemi döneminde artan iş yükleri, enfeksiyon kapma riskleri, çevrelerine enfeksiyon bulaştırma korkusu stres seviyelerini arttırmakta ve bu durumda tükenmişlik düzeylerini etkilemektedir. Yaşanan tükenmişlik sonucunda, sağlık çalışanları kadar, hizmet talep edenlerde risk altındadır. Sağlık çalışanlarının Covid-19 döneminde yaşamakta oldukları stres ve tükenmişlik düzeylerini belirlemek ve bu tükenmişlik düzeylerini en alt seviyede tutmak, hem sağlık çalışanları açısından hem de hizmet talep edenler açısından kritik öneme sahiptir. Bu sebeple, çalışmanın temel amacı, sağlık çalışanlarının tükenmişlik düzeylerini incelemek ve Covid-19 pandemisinde çalışma şartlarının bu tükenmişlik düzeyleri üzerine etkisini belirlemektir.

\subsection{Araştırma Hipotezleri}

Bu çalışmada sağlık çalışanlarının tükenmişlik düzeyleri incelenmiş olup, Covid-19 pandemi sürecinin bu tükenmişlik düzeyleri üzerine etkisini belirlemek amaçlanmıştır. $\mathrm{Bu}$ amaçla toplam beş hipotez geliştirilmiş olup, söz konusu hipotezler aşağıda verilmiştir:

$\mathrm{H}_{1}$ : Sağlık çalışanlarının duygusal tükenme, duyarsızlaşma ve kişisel başarı azalma hissi düzeyleri ile sosyo-demografik özellikleri arasında ilişki vardır.

$\mathrm{H}_{2}$ : Sağlık çalışanlarının duygusal tükenme, duyarsızlaşma ve kişisel başarı azalma hissi düzeyleri ile çalıştıkları birim arasında ilişki vardır.

$\mathrm{H}_{3}$ : Sağlık çalışanlarının duygusal tükenme, duyarsızlaşma ve kişisel başarı azalma hissi düzeyleri ile çalışma saatleri arasında ilişki vardır.

$\mathrm{H}_{4}$ : Sağlık çalışanlarının duygusal tükenme, duyarsızlaşma ve kişisel başarı azalma hissi düzeyleri ile çalışma ortamı arasında ilişki vardır

$\mathrm{H}_{5}$ : Sağglık çalışanlarının duygusal tükenme, duyarsızlaşma ve kişisel başarı azalma hissi düzeyleri ile Covid-19 pandemisi stres düzeyleri arasında ilişki vardır. 


\subsection{Araştırmanın Evren ve Örneklemi}

Araştırmanın evrenini, İstanbul'da faaliyet gösteren iki Eğitim-Araştırma Hastanesi ve iki kamu hastanesinde çalışan toplam 4960 sağlık çalışanı oluşturmaktadır. Araştırmanın yürütüleceği hastaneler belirlendikten sonra Kolayda Örneklem Yöntemi ile örneklem sayısı belirlenmiştir. Örneklem sayısı ise, 4960 kişilik evren için \%95 güvenilirlik düzeyinde $(\mathrm{t}=1.96 \mathrm{p}=0.5 \quad \mathrm{q}=0.5 \quad \mathrm{~d}=0.05 \quad \alpha=0.05) \quad 357 \quad$ sağlı çalışanı olarak belirlenmiş (Yazıcıoğlu \& Erdoğan, 2004 s. 50), ancak 352 sağlık çalışanı araştırmaya katılmaya gönüllü olmuştur.

\subsection{Veri Toplama Araçları}

Araştırma verilerini elde etmek amacıyla anket tekniği kullanılmıştır. Çalışma soruları, Google Forms üzerinde oluşturularak sağlık çalışanlarına E-Mail yoluyla ulaştırılmıştır. Çalışmaya başlanmadan önce Ankara Hacı Bayram Veli Üniversitesi etik kurulundan onay alınmıştır. Çalışma verileri 21 Haziran, 21 Temmuz 2021 tarihleri arasında toplanmıştır.

Çalışmanın anketi iki bölümden oluşmaktadır. Birinci bölümde, katılımcıların demografik bilgileri ve çalışma durumlarına ilişkin bilgilerin yer aldığı kişisel bilgi formu, ikinci bölümde ise tükenmişlik düzeylerini belirlemek amacıyla Maslach Tükenmişlik Ölçeği kullanılmıştır. Maslach Tükenmişlik Ölçeği-Sağlık Personeli Formu MTÖ-SP, tükenmişliği ölçmek amacıyla 1981 yılında Christina Maslach ve Susan E. Jackson tarafından geliştirilmiş olup, Ergin (1992) tarafından sağlık çalışanları için özel olarak Türkçe geçerlilik güvenilirlik çalışması yapılmıştır. Üç faktörlü yapı duygusal tükenme, duyarsızlaşma ve kişisel başarı azalması hissinden oluşmaktadır. Katılımcıların yorgunluk ve duygusal yönden yıpranmışlık durumunu ölçen duygusal tükenme alt ölçeği 1, 2, 3, 6, 8, 13, 14, 16, 20 numaralı sorular ile değerlendirilmektedir. Katılımcının hizmet verdiği diğer bireylere karşı duygudan yoksun şekilde davranışlarını ölçen duyarsızlaşma alt ölçeği 5, 10, 11, 15, 22 numaralı sorular ile değerlendirilmektedir. Katılımcının işindeki yeterlilik duygularını ölçen kişisel başarı azalması hissi alt ölçeği ise 4, 7, 9, 12, 17, 18, 19, 21 numaraları sorular ile değerlendirilmektedir. Duygusal tükenme alt ölçeği 9 sorudan oluşmakta olup, alınacak en yüksek puan 54'tür. 27 puan ve üstü yüksek tükenme 16-27 puan arası orta düzey tükenme, 16 puan ve altı ise düşük düzey tükenme olarak değerlendirilmiştir. Duyarsızlaşma alt ölçeği 5 sorudan oluşmakta olup, alınabilecek en yükssek puan 30'dur. 13 puan ve üstü yüksek seviye duyarsızlaşma, 6-13 puan arası orta seviye duyarsızlaşma, 6 puan ve altı ise düşük seviye duyarsızlaşma olarak değerlendirilmiştir. Kişisel başarı hissinde azalma hissi ise 8 soru ile değerlendirilmektedir. Alınabilecek en yüksek puan 48 olup, 21 puan ve altı yüksek seviye, 21-39 puan arası orta 
seviye 39 puan ve üzeri ise düşük seviye kişisel başarı azalması hissi olarak değerlendirilmiştir. Ölçek maddeleri olarak orijinal Maslach tükenmişlik ölçeğindeki cevaplar ve puanlama sistemi kullanılmıştır. "0-hiçbir zaman” ve "6-her zaman” aralığında puanlanmaktadır. Duygusal tükenme ve duyarsızlaşma alt ölçeklerindeki yüksek puan, kişisel başarı azalması hissi alt ölçeğindeki düşük puan tükenmişliği göstermektedir. Puanlamada, her bir kişi için üç ayrı tükenmişlik puanı hesaplanmaktadır.

\section{5. Çalışmanın Sınırlılıkları}

Araştırma bulguları, İstanbul'da faaliyet gösteren iki Eğitim-Araştırma Hastanesi ve iki kamu hastanesinde çalışan sağlık çalışanlarından elde edilen verilerle sınırlıdır.

\section{Bulgular}

Tablo 1'de katılımcıların demografik özellikleri ve tanımlayıcı özelliklerine ait verilerin analizi yer almaktadır. Araştırmaya 352 sağlık çalışanı dâhil edilmiştir. Bu verilere göre katılımcıların \%53,4'ü erkek, \%44,3'ü 26-35 yaş aralığında, \%73'ü evli, \%39,8'i lisans eğitimi aldığını belirtmiştir. Katılımcıların \%65,6'sı çocuk sahibi olduğu, \%33,8’i de iki çocuk sahibi olduğunu ifade etmiştir. Katılımcıların \%67'si sigara kullanmamakta, \%76,7'si Covid-19 hastalığı geçirmemiştir. Katılımcıların \%47,4'lük kısmının poliklinik biriminde çalıştı̆ğ, belirlenmiştir. Katılımcıların \%88,9'u aile veya arkadaşları ile birlikte yaşadıklarını belirtmiş, Covid-19 sonrasında \%76,1'lik kısım aileden ayrı yaşamadıklarını belirtmişlerdir. Covid-19'un stres seviyesini artırdığını belirten katılımcı oranı \%83,2'dir. Katılımcıların \%52'si hem gece hem gündüz, \%65,1'i 46 saat ve üzeri çalıştığını belirtmiştir. Katılımcıların \%86,4'ü mesleğini isteyerek seçtiğini, \%85,2'si mesleğinin kendisine uygun olduğunu, \%77,8'i ise çalışma ortamından memnun olduğunu belirtmiştir. Katılımcıların \%76,4'ü çalışırken dinlenme imkânı olduğunu, \% 59, 1'i yeterli düzeyde dinlenebildiğini, \%93,5'i de çalışırken yemek yemeye fırsat bulabildiğini belirtmiştir.

Tablo 1: Katılımcıların Demografik Özellikleri $(n=352)$

\begin{tabular}{lcc}
\hline Demografik Bilgiler & n & \% \\
\hline Cinsiyet & 164 & 46,6 \\
Kadın & 188 & 53,4 \\
Erkek & & \\
\hline Medeni Durum & 257 & 73,0 \\
Evli & 95 & 27,0 \\
Bekâr
\end{tabular}




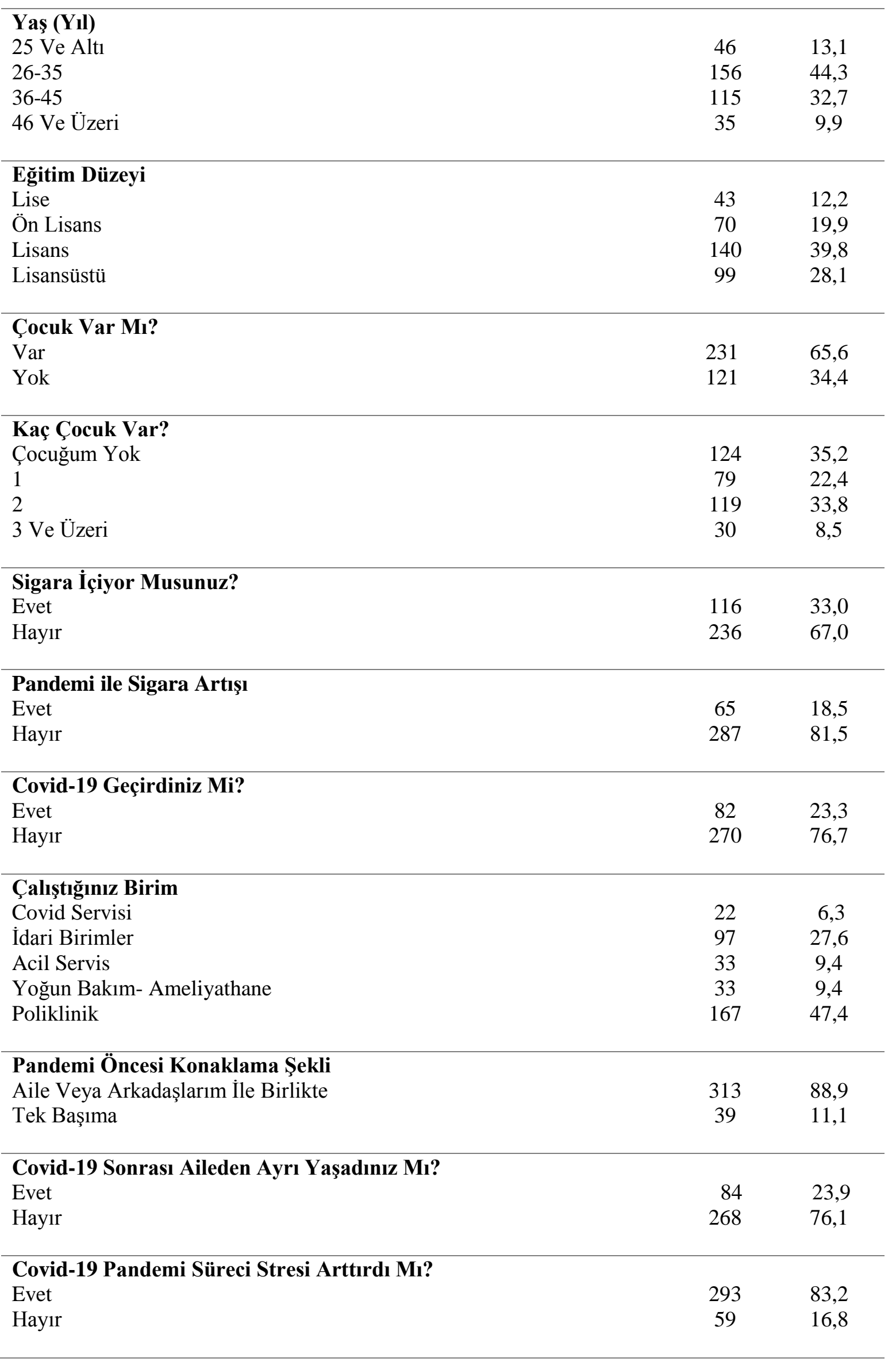




\begin{tabular}{|c|c|c|}
\hline $\begin{array}{l}\text { Mesai Şekliniz } \\
\text { Sadece Gündüz } \\
\text { Gece Gündüz }\end{array}$ & $\begin{array}{l}169 \\
183\end{array}$ & $\begin{array}{l}48,0 \\
52,0\end{array}$ \\
\hline $\begin{array}{l}\text { Haftada Kaç Saat Çalışıorsunuz? } \\
25 \text { Saat Ve Altı } \\
\text { 26-45 Saat } \\
45 \text { Saat Ve Üzeri }\end{array}$ & $\begin{array}{c}57 \\
66 \\
229\end{array}$ & $\begin{array}{l}16,2 \\
18,8 \\
65,1\end{array}$ \\
\hline $\begin{array}{l}\text { Mesleğinizi İsteyerek Mi Seçtiniz? } \\
\text { Evet } \\
\text { Hayır }\end{array}$ & $\begin{array}{c}304 \\
48\end{array}$ & $\begin{array}{l}86,4 \\
13,6\end{array}$ \\
\hline $\begin{array}{l}\text { Mesleğiniz Size Uygun Mu? } \\
\text { Uygun } \\
\text { Uygun Değil }\end{array}$ & $\begin{array}{c}300 \\
52\end{array}$ & $\begin{array}{l}85,2 \\
14,8\end{array}$ \\
\hline $\begin{array}{l}\text { Çalışma Ortamından Memnun Musunuz? } \\
\text { Evet } \\
\text { Hayır }\end{array}$ & $\begin{array}{c}274 \\
78\end{array}$ & $\begin{array}{l}77,8 \\
22,2\end{array}$ \\
\hline $\begin{array}{l}\text { Çalışırken Dinlenme Fırsatınız Oluyor Mu? } \\
\text { Evet } \\
\text { Hayır }\end{array}$ & $\begin{array}{c}269 \\
83\end{array}$ & $\begin{array}{l}76,4 \\
23,6\end{array}$ \\
\hline $\begin{array}{l}\text { Yeterli Dinlenmiş Oluyor Musunuz? } \\
\text { Evet } \\
\text { Hayır }\end{array}$ & $\begin{array}{l}208 \\
144\end{array}$ & $\begin{array}{l}59,1 \\
40,9\end{array}$ \\
\hline $\begin{array}{l}\text { Çalışma Saatlerinde Yemek Firsatı Oluyor Mu? } \\
\text { Evet } \\
\text { Hayır }\end{array}$ & $\begin{array}{c}329 \\
23\end{array}$ & $\begin{array}{c}93,5 \\
6,5\end{array}$ \\
\hline
\end{tabular}

Katılımcıların tükenmişlik düzeylerini belirlemek üzere kullanılan ölçek üç boyuttan oluşmaktadır. Bu boyutlar; duygusal tükenme, duyarsızlaşma ve kişisel başarı azalma hissidir. Boyutlara ilişkin ifadelerin güvenilirliğini belirlemek üzere yapılan analiz bulguları Tablo 2'de yer almaktadır.

Tablo2: Tükenmişlik Düzeyleri Boyutlarına İlişkin Güvenirlik Katsayıları

\begin{tabular}{lcc}
\hline Boyutlar & Cronbach's Alfa & Ífade Sayısı \\
\hline Duygusal tükenme &, 960 & 9 \\
\hline Duyarsızlaşma &, 855 & 5 \\
\hline $\begin{array}{l}\text { Kişisel Başarı Azalma } \\
\text { Hissi }\end{array}$ &, 964 & 8 \\
\hline Genel & & \\
\hline
\end{tabular}


$\mathrm{Bu}$ araştırma kapsamında yapılan güvenilirlik analizleri sonucunda ölçeğin bütünü için Cronbach Alfa katsayısı 0,909; ölçeğin alt boyutlarının Cronbach Alfa katsayıları: duygusal tükenme için 0,960; duyarsızlaşma için 0,855; kişisel başarı azalma hissi için 0,964 olarak hesaplanmıştır.

Tablo 3: Ölçeğe İlişkin Tek Boyutluluk Analiz Sonuçları

\begin{tabular}{|c|c|}
\hline Boyut & Faktör yükü \\
\hline \multicolumn{2}{|c|}{ Duygusal Tükenme } \\
\hline MTÖ1 & 916 \\
\hline MTÖ2 & ,932 \\
\hline MTÖ3 & 922 \\
\hline MTÖ6 & ,815 \\
\hline MTÖ8 & ,903 \\
\hline MTÖ13 &, 880 \\
\hline MTÖ14 & ,867 \\
\hline MTÖ16 & ,846 \\
\hline MTÖ20 & 757, \\
\hline & KMO; ,921 \\
\hline \multicolumn{2}{|c|}{ Duyarsızlaşma } \\
\hline MTÖ5 & 706 \\
\hline MTÖ10 & 884, \\
\hline MTÖ11 & 893 \\
\hline MTÖ15 & 680 \\
\hline MTÖ22 & ,795 \\
\hline & KMO; ,801 \\
\hline \multicolumn{2}{|c|}{ Kişisel Başarı Azalma Hissi } \\
\hline MTÖ4 & 903, \\
\hline MTÖ7 & ,912 \\
\hline MTÖ9 & ,917 \\
\hline MTÖ12 & 801 \\
\hline MTÖ17 & ,927 \\
\hline MTÖ18 & 885 \\
\hline MTÖ19 & ,937 \\
\hline MTÖ21 & 866 \\
\hline
\end{tabular}


Tablo 3 incelendiğinde ölçekte yer alan her bir boyuta ait ifadelerin faktör yüklerinin 0,50'nin üzerinde olduğu görülmektedir. $\mathrm{Bu}$ nedenle ölçekten herhangi bir ifade çıkartılmamıştır.

Tablo4: Tükenmişlik Boyutlarının Düzeyine İlişkin Veriler

\begin{tabular}{|l|l|l|l|l|l|r|}
\hline \multirow{2}{*}{} & \multicolumn{2}{|c|}{ Yüksek } & \multicolumn{2}{c|}{ Orta } & \multicolumn{2}{c|}{ Düşük } \\
\cline { 2 - 7 } & \multicolumn{1}{|c|}{$\mathbf{n}$} & \% & \multicolumn{1}{c|}{ n } & \% & n & \% \\
\hline Duygusal tükenme & 69 & 19,6 & 46 & 13,1 & 237 & 67,3 \\
\hline Duyarsızlaşma & 59 & 16,8 & 40 & 11,4 & 253 & 71,9 \\
\hline $\begin{array}{l}\text { Kişisel başarı azalma } \\
\text { hissi }\end{array}$ & 95 & 27,0 & 114 & 32,4 & 143 & 40,6 \\
\hline
\end{tabular}

Tablo 4'te tükenmişlik boyutlarının düzeyine ilişkin veriler yer almaktadır. Bu verilere göre katılımcıların \%67,3 oranında düşük duygusal tükenmeye sahip oldukları belirlenmiştir. Katılımcıların \%71,9 oranında düşük düzeyde duyarsızlaşmaya sahip oldukları ve \%40,6 düşük düzeyde kişisel başarı azalma hissine sahip oldukları belirlenmiştir.

Tablo5: Maslach Tükenmişlik Ölçeğinin Duygusal Tükenme Düzeyine Göre Araştırmaya Katılan Sağlık Çalışanlarının Bazı Tanımlayıcı Özelliklerinin Dağılımı

\begin{tabular}{|c|c|c|c|c|c|c|c|c|}
\hline & \multicolumn{6}{|c|}{ DUYGUSAL TÜKENME } & \multirow{3}{*}{$X^{2}$} & \multirow{3}{*}{$\mathrm{P}^{*}$} \\
\hline & \multicolumn{2}{|c|}{ Yüksek } & \multicolumn{2}{|c|}{ Orta } & \multicolumn{2}{|c|}{ Düșük } & & \\
\hline & $\mathrm{N}$ & $\%$ & $\mathrm{~N}$ & $\%$ & $\mathrm{~N}$ & $\%$ & & \\
\hline & \multicolumn{8}{|c|}{ Cinsiyet } \\
\hline Kadın & 50 & 72,5 & 26 & 56,5 & 88 & 37,1 & 28.909 & .00 \\
\hline Erkek & 19 & 27,5 & 20 & 43,5 & 149 & 62,9 & & \\
\hline Toplam & 69 & 100,0 & 46 & 100 & 237 & 100,0 & & \\
\hline \multicolumn{9}{|l|}{\begin{tabular}{l|l} 
& Yaş
\end{tabular}} \\
\hline 25 yaş ve alt & 18 & 26,1 & 7 & 15,2 & 21 & 8,9 & 35.599 & .00 \\
\hline $26-35$ & 37 & 53,6 & 27 & 58,7 & 92 & 38,8 & & \\
\hline $36-45$ & 8 & 11,6 & 9 & 19,6 & 98 & 41,4 & & \\
\hline 46 ve üzeri & 6 & 8,7 & 3 & 6,5 & 26 & 11,0 & & \\
\hline Toplam & 69 & 100,0 & 46 & 100,0 & 237 & 100,0 & & \\
\hline \multicolumn{9}{|c|}{ Medeni Durum } \\
\hline Evli & 44 & 63,8 & 30 & 65,2 & 183 & 77,2 & 6.535 & 0.03 \\
\hline Bekâr & 25 & 36,2 & 16 & 34,8 & 54 & 22,8 & & \\
\hline Toplam & 69 & 100,0 & 46 & 100,0 & 237 & 100,0 & & \\
\hline \multicolumn{9}{|c|}{\begin{tabular}{|l|l} 
& Eğitim durumu
\end{tabular}} \\
\hline Lise & 5 & 7,2 & 1 & 2,2 & 37 & 15,6 & 11.861 & 0.06 \\
\hline Ön lisans & 11 & 15,9 & 10 & 21,7 & 49 & 20,7 & & \\
\hline Lisans & 32 & 46,4 & 17 & 37,0 & 91 & 38,4 & & \\
\hline Lisansüstü & 21 & 30,4 & 18 & 39,1 & 60 & 25,3 & & \\
\hline
\end{tabular}




\begin{tabular}{|c|c|c|c|c|c|c|c|c|}
\hline \multirow{2}{*}{\multicolumn{2}{|c|}{$\begin{array}{l}\text { Toplam } \\
\text { Çalıştığınız birim }\end{array}$}} & 100,0 & 46 & 100,0 & 237 & 100,0 & & \\
\hline & & & & & & & & \\
\hline $\begin{array}{l}\text { Covid-19 } \\
\text { servisi }\end{array}$ & 8 & 11,6 & 8 & 17,4 & 6 & 2,5 & 42.098 & .00 \\
\hline İdari birimler & 13 & 18,8 & 7 & 15,2 & 77 & 32,5 & & \\
\hline $\begin{array}{l}\text { Acil servis ve } \\
\text { ekibi }\end{array}$ & 7 & 10,1 & 5 & 10,9 & 21 & 8,9 & & \\
\hline $\begin{array}{l}\text { Yoğun bakım- } \\
\text { ameliyathane }\end{array}$ & 11 & 15,9 & 10 & 21,7 & 12 & 5,1 & & \\
\hline Poliklinik & 30 & 43,5 & 16 & 34,8 & 121 & 51,1 & & \\
\hline Toplam & 69 & 100,0 & 46 & 100,0 & 237 & 100,0 & & \\
\hline \multicolumn{9}{|c|}{ Haftalık çalışma saati } \\
\hline 25 saat ve alt 1 & 20 & 29,0 & 10 & 21,7 & 27 & 11,4 & 13.995 & .00 \\
\hline $26-45$ saat & 13 & 18,8 & 7 & 15,2 & 46 & 19,4 & & \\
\hline $\begin{array}{l}46 \text { saat ve } \\
\text { üzeri }\end{array}$ & 36 & 52,2 & 29 & 63,0 & 164 & 69,2 & & \\
\hline Toplam & 69 & 100,0 & 46 & 100,0 & 237 & 100,0 & & \\
\hline \multicolumn{9}{|c|}{ Çalışma ortamından memnun musunuz? } \\
\hline Evet & 26 & 37,7 & 31 & 67,4 & 217 & 91,6 & 93.294 & .00 \\
\hline \multirow{2}{*}{$\begin{array}{l}\text { Hayır } \\
\text { Toplam }\end{array}$} & 43 & 62,3 & 15 & 32,6 & 20 & 8,4 & & \\
\hline & 69 & 100,0 & 46 & 100,0 & 237 & 100,0 & & \\
\hline \multicolumn{9}{|c|}{ Covid-19 stres düzeyini arttırdı mı? } \\
\hline Evet & 68 & 98,6 & 41 & 89,1 & 184 & 77,6 & 18.070 & .00 \\
\hline Hayır & 1 & 1,4 & 5 & 10,9 & 53 & 22,4 & & \\
\hline Toplam & 69 & 100,0 & 46 & 100,0 & 237 & 100,0 & & \\
\hline $\mathrm{n}$ : Hast & ISI; \% & In yüzde & ; *Ki-Kar & & & & & \\
\hline
\end{tabular}

Tablo 5'te araştırmaya katılan sağlık çalışanlarının cinsiyet durumu ile duygusal tükenme arasında istatistiksel olarak anlamlı ilişki bulunmaktadır $(\mathrm{p}<0.05)$. Yüksek duygusal tükenme yaşayan katılımcıların yüzdeleri incelendiğinde kadınların \%72,5, erkeklerin \%27,5 yüksek duygusal tükenme yaşadıkları görülmektedir. Orta düzey duygusal tükenmede çok büyük farkl1lık görülmezken, düşük duygusal tükenme yaşayan katılımcılar \%62,9 ile erkeklerdir. Araştırmaya katılan sağlık çalışanlarının yaş durumu ile duygusal tükenme arasında istatistiksel olarak anlamlı ilişki bulunmaktadır ( $\mathrm{p}<0.05$ ). 25 yaş ve altı grubunda \%26,1, 26-35 yaş grubunda $\% 53,6,36-45$ yaş grubunda $\% 11,6$ ve 46 yaş ve üzeri grupta $\% 8,7$ oranında yüksek düzeyde duygusal tükenme yaşandığı sonucuna ulaşılmıştır. 25 yaş ve altı grubunda $\% 15,2,26-35$ yaş grubunda \%58,7, 36-45 yaş grubunda \%19,6 ve 46 yaş ve üzeri grupta \%6,5 oranında orta düzeyde duygusal tükenme yaşandığı sonucuna ulaşılmıştır. 25 yaş ve altı grubunda \%8,9, 26-35 yaş grubunda \%38,8, 36-45 yaş grubunda \%41,4 ve 46 yaş ve üzeri grupta \%11,0 oranında düşük düzeyde duygusal tükenme yaşandığı sonucuna ulaşılmıştır. Araştırmaya katılan sağlık çalışanlarının medeni durumu ile duygusal tükenme arasında 
istatistiksel olarak anlamlı ilişki bulunmaktadır ( $\mathrm{p}<0.05)$. Evli katılımcıların \%63,8, bekâr katılımcıların \%32,0 ile yüksek duygusal tükenme yaşadıkları görülmüştür. Evli katılımcıların \%65,2 ile orta düzeyde, bekârların ise \%34,8 ile orta düzeyde duygusal tükenme yaşadıkları görülürken, evlilerin \%77,2 ile düşük duygusal tükenme yaşadıkları bekârların ise, \%22,8 düşük duygusal tükenme yaşadıkları sonucuna ulaşılmıştır. Bu sonuçlara göre araştırma hipotezi olarak ileri sürülen $\mathrm{H}_{1}$ hipotezi yaş, cinsiyet ve medeni durum için kabul edilirken, eğitim durumu için red edilmiştir. Araştırmaya katılan sağlık çalışanlarının çalıştı̆̆ birim ile duygusal tükenme arasında istatistiksel olarak anlamlı ilişki bulunmaktadır ( $\mathrm{p}<0.05$ ). Covid-19 servisinde görev yapan sağlık çalışanlarının $\% 11,6$, idari birimlerde görev yapanların $\% 18,8$, acil servis ve ekibinde yer alanların \%10,1, yoğun bakım ve ameliyathanede görev yapanların $\% 15,9$ ve polikliniklerde görev yapanların \%43,5 ile yüksek düzeyde duygusal tükenme yaşadıkları sonucuna ulaşılmıştır. Diğer yandan covid-19 servisinde görev yapan sağlık çalışanlarının \%17,4, idari birimlerde görev yapanların \%15,2, acil servis ve ekibinde yer alanların \%10,9, yoğun bakım ve ameliyathanede görev yapanların $\% 21,7$ ve polikliniklerde görev yapanların \%34,8 ile orta düzeyde duygusal tükenme yaşadıkları sonucuna ulaşılmıştır. Covid-19 servisinde görev yapan sağlık çalışanlarının \%2,5, idari birimlerde görev yapanların $\% 32,5$, acil servis ve ekibinde yer alanların \%8,9, yoğun bakım ve ameliyathanede görev yapanların $\% 5,1$ ve polikliniklerde görev yapanların \%51,1 ile düşük düzeyde duygusal tükenme yaşadıkları sonucuna ulaşılmıştır. Bu sonuçlara göre araştırma hipotezi olarak ileri sürülen $\mathrm{H}_{2}$ hipotezi kabul edilmiştir. Araştırmaya katılan sağlık çalışanlarının haftalık çalışma saatleri ile duygusal tükenme arasında istatistiksel olarak anlamlı ilişki bulunmaktadır $(\mathrm{p}<0.05)$. Katılımcılardan 25 saat ve altı çalışanların \%29,0, 26-45 saat arası çalışanların \%18,8, 46 saat ve üzeri çalışanların \%52,2 oranında yüksek düzeyde duygusal tükenme yaşadığı sonucuna ulaşılmıştır. Katılımcılardan 25 saat ve altı çalışanların \%21,7, 26-45 saat arası çalışanların \%15,2, 46 saat ve üzeri çalışanların \%63,0 oranında orta düzeyde duygusal tükenme yaşadığ sonucuna ulaşılmıştır. Katılımcılardan 25 saat ve altı çalışanların \%11,4, 26-45 saat arası çalışanların \%19,4, 46 saat ve üzeri çalışanların \%69,2 oranında düşük düzeyde duygusal tükenme yaşadığı sonucuna ulaşılmıştır. Bu sonuçlara göre araştırma hipotezi olarak ileri sürülen $\mathrm{H}_{3}$ hipotezi kabul edilmiştir. Araştırmaya katılan sağlık çalışanlarının haftalık çalışma ortamından memnuniyet durumu ile duygusal tükenme arasında istatistiksel olarak anlamlı ilişki bulunmaktadır ( $\mathrm{p}<0.05)$. Çalışma ortamından memnun olan sağlık çalışanlarının \%37,7 oranında iken, memnun olmayanların \%62,3 oranında duygusal tükenme yaşadığı sonucuna ulaşılmıştır. Çalışma ortamından memnun olan sağlık çalışanlarının \%91,6 ile düşük düzeyde duygusal tükenme yaşarken, çalışma ortamından memnun olmayanların \%8,4 oranında düşük 
düzeyde duygusal tükenme yaşadıkları sonucuna ulaşılmıştır. Bu sonuçlara göre araştırma hipotezi olarak ileri sürülen $\mathrm{H}_{4}$ hipotezi kabul edilmiştir. Araştırmaya katılan sağlık çalışanlarının covid-19 pandemisinin stres düzeyini arttırma durumu ile duygusal tükenme arasında istatistiksel olarak anlamlı ilişki bulunmaktadır $(\mathrm{p}<0.05)$. Covid-19 pandemisinde stres düzeylerinin arttığını belirten sağlık çalışanlarının \%98,6 oranında yüksek, stres düzeylerinde artış olmadığını belirten sağlık çalışanlarının ise \%1,4 ile yüksek duygusal tükenme yaşadıkları belirlenmiştir. Stres düzeylerinin arttığını belirten sağlık çalışanları \% 89,1 oranında orta düzeye duygusal tükenme yaşarken bu oran stres düzeylerinin artmadığını belirten sağlık çalışanlarında \%10,9'dur. Düşük düzeyde duygusal tükenme yaşayan sağlık çalışanlarında ise bu oran stres düzeyinin arttığını belirtenlerde \%77,6 iken, stres düzeyinin artmadığını belirtenlerde ise, \%22,4'tür. Bu sonuçlara göre araştırma hipotezi olarak ileri sürülen $\mathrm{H}_{5}$ hipotezi kabul edilmiştir. Diğer taraftan Maslach Tükenmişlik Ölçeğinin duygusal tükenme düzeyi ile eğitim durumları arasında istatistiksel olarak anlamlı bir ilişki saptanmamıştır $(\mathrm{p}>0,05)$.

Maslach Tükenmişlik Ölçeğinin duyarsızlaşma düzeyine göre araştırmaya katılan sağlık çalışanlarının bazı tanımlayıcı özelliklerinin dağılımı Tablo 6'da sunulmuştur.

Tablo6: Maslach Tükenmişlik Ölçeğinin duyarsızlaşma düzeyine göre araştırmaya katılan sağlık çalışanlarının bazı tanımlayıcı özelliklerinin dağılımı

\begin{tabular}{|c|c|c|c|c|c|c|c|c|}
\hline & \multicolumn{6}{|c|}{ DUYARSIZLAŞMA } & \multirow[t]{3}{*}{$X^{2}$} & \multirow[t]{3}{*}{$\mathrm{P}^{*}$} \\
\hline & \multicolumn{2}{|c|}{ Yüksek } & \multicolumn{2}{|c|}{ Orta } & \multirow{2}{*}{$\begin{array}{c}\text { Düşük } \\
\text { N }\end{array}$} & \multirow[b]{2}{*}{$\%$} & & \\
\hline & $\mathrm{N}$ & $\%$ & $\mathrm{~N}$ & $\%$ & & & & \\
\hline \multicolumn{9}{|c|}{ Cinsiyet } \\
\hline Kadın & 40 & 67,8 & 20 & 50,0 & 104 & 41,1 & 13.907 & .00 \\
\hline Erkek & 19 & 32,2 & 20 & 50,0 & 149 & 58,9 & & \\
\hline Toplam & 59 & 100,0 & 40 & 100,0 & 253 & 100,0 & & \\
\hline \multicolumn{9}{|l|}{ Yaş } \\
\hline 25 yaş ve altı & 14 & 23,7 & 8 & 20,0 & 24 & 9,5 & 28.996 & .00 \\
\hline $26-35$ & 33 & 55,9 & 19 & 47,5 & 104 & 41,1 & & \\
\hline $36-45$ & 8 & 13,6 & 6 & 15,0 & 101 & 39,9 & & \\
\hline 46 ve üzeri & 4 & 6,8 & 7 & 17,5 & 24 & 9,5 & & \\
\hline Toplam & 59 & 100,0 & 40 & 100,0 & 253 & 100,0 & & \\
\hline \multicolumn{9}{|c|}{ Medeni Durum } \\
\hline Evli & 41 & 69,5 & 28 & 70,0 & 188 & 74,3 & .771 & 0.68 \\
\hline Bekâr & 18 & 30,5 & 12 & 30,0 & 65 & 25,7 & & \\
\hline Toplam & 59 & 100,0 & 40 & 100,0 & 253 & 100,0 & & \\
\hline \multicolumn{9}{|c|}{ Eğitim durumu } \\
\hline Lise & 3 & 5,1 & 4 & 10,0 & 36 & 14,2 & 6.072 & 0.41 \\
\hline Ön lisans & 10 & 16,9 & 7 & 17,5 & 53 & 20,9 & & \\
\hline Lisans & 25 & 42,4 & 16 & 40,0 & 99 & 39,1 & & \\
\hline Lisansüstü & 21 & 35,6 & 13 & 32,5 & 65 & 25,7 & & \\
\hline Toplam & 59 & 100,0 & 40 & 100,0 & 253 & 100,0 & & \\
\hline
\end{tabular}




\begin{tabular}{|c|c|c|c|c|c|c|c|c|}
\hline \multicolumn{9}{|c|}{ Çalıştığınız birim } \\
\hline $\begin{array}{l}\text { Covid-19 } \\
\text { servisi }\end{array}$ & 7 & 11,9 & 6 & 15,0 & 9 & 3,6 & 27.236 & .00 \\
\hline İdari birimler & 10 & 16,9 & 8 & 20,0 & 79 & 31,2 & & \\
\hline $\begin{array}{l}\text { Acil servis ve } \\
\text { ekibi }\end{array}$ & 8 & 13,6 & 2 & 5,0 & 23 & 9,1 & & \\
\hline $\begin{array}{l}\text { Yoğun bakım- } \\
\text { ameliyathane }\end{array}$ & 10 & 16,9 & 7 & 17,5 & 16 & 6,3 & & \\
\hline Poliklinik & 24 & 40,7 & 17 & 42,5 & 126 & 49,8 & & \\
\hline Toplam & 59 & 100,0 & 40 & 100,0 & 253 & 100,0 & & \\
\hline \multicolumn{9}{|c|}{ Haftalık çalışma saati } \\
\hline 25 saat ve altı & 14 & 23,7 & 5 & 12,5 & 38 & 15,0 & 3.714 & 0.44 \\
\hline $26-45$ saat & 12 & 20,3 & 7 & 17,5 & 47 & 18,6 & & \\
\hline $\begin{array}{l}46 \text { saat ve } \\
\text { üzeri }\end{array}$ & 33 & 55,9 & 28 & 70,0 & 168 & 66,4 & & \\
\hline Toplam & 59 & 100,0 & 40 & 100,0 & 253 & 100,0 & & \\
\hline \multicolumn{9}{|c|}{ Çalışma ortamından memnun musunuz? } \\
\hline Evet & 19 & 32,2 & 30 & 75,0 & 225 & 88,9 & 89.475 & .00 \\
\hline Hayır & 40 & 67,8 & 10 & 25,0 & 28 & 11,1 & & \\
\hline Toplam & 59 & 100,0 & 40 & 100,0 & 253 & 100,0 & & \\
\hline \multicolumn{9}{|c|}{ Covid-19 stres düzeyini arttırdı mı? } \\
\hline Evet & 58 & 98,3 & 37 & 92,5 & 198 & 78,3 & 16.552 & .00 \\
\hline Hayır & 1 & 1,7 & 3 & 7,5 & 55 & 21,7 & & \\
\hline Toplam & 59 & 100,0 & 40 & 100,0 & 253 & 100,0 & & \\
\hline
\end{tabular}

Tablo 6'da araştırmaya katılan sağlık çalışanlarının cinsiyet durumu ile duyarsızlaşma boyutu arasında istatistiksel olarak anlamlı ilişki bulunmaktadır $(\mathrm{p}<0.05)$. Araştırmaya katılan kadın katılımcıların \%67,8 oranında, erkek katılımcıların ise, \%32,2 oranında duyarsızlaşma yaşadıkları sonucuna ulaşılmıştır. Orta düzeyde fark bulunmazken, düşük düzeyde kadın katılımcıların \%41,1 oranında, erkeklerin ise \%58,9 oranında düşük düzeyde duyarsızlaşma yaşadıkları belirlenmiştir. Araştırmaya katılan sağlık çalışanlarının yaş durumu ile duyarsızlaşma arasında istatistiksel olarak anlamlı ilişki bulunmaktadır ( $\mathrm{p}<0.05)$. 25 yaş ve altı grubunda $\% 23,7,26-35$ yaş grubunda $\% 55,9,36-45$ yaş grubunda $\% 13,6$ ve 46 yaş ve üzeri grupta \%6,8 oranında yüksek düzeyde duyarsızlaşma yaşandığı sonucuna ulaşılmıştır. 25 yaş ve alt1 grubunda \%20,0, 26-35 yaş grubunda \%47,5, 36-45 yaş grubunda \%15,0 ve 46 yaş ve üzeri grupta \%17,5 oranında orta düzeyde duyarsızlaşma yaşandığı sonucuna ulaşılmıştır. 25 yaş ve altı grubunda \%9,5, 26-35 yaş grubunda \%41,1, 36-45 yaş grubunda $\% 39,9$ ve 46 yaş ve üzeri grupta \%9,5 oranında düşük düzeyde duyarsızlaşma yaşandığı sonucuna ulaşılmıştır. $\mathrm{Bu}$ sonuçlara göre araştırma hipotezi olarak ileri sürülen $\mathrm{H}_{1}$ hipotezi yaş, cinsiyet ve eğitim durumu için kabul edilirken, medeni durum için ret edilmiştir. Araştırmaya katılan sağlık 
çalışanlarının çalıştı̆̆ birim ile duygusal tükenme arasında istatistiksel olarak anlamlı ilişki bulunmaktadır ( $\mathrm{p}<0.05$ ). Covid-19 servisinde görev yapan sağlık çalışanlarının \%11,9, idari birimlerde görev yapanların \%16,9, acil servis ve ekibinde yer alanların \%13,6, yoğun bakım ve ameliyathanede görev yapanların \%16,9 ve polikliniklerde görev yapanların \%40,7 ile yüksek düzeyde duyarsızlaşma yaşadıkları sonucuna ulaşılmıştır. Diğer yandan Covid-19 servisinde görev yapan sağlık çalışanlarının $\% 15,0$, idari birimlerde görev yapanların $\% 20,0$, acil servis ve ekibinde yer alanların \%5,0, yoğun bakım ve ameliyathanede görev yapanların $\% 17,5$ ve polikliniklerde görev yapanların $\% 42,5$ ile orta düzeyde duyarsızlaşma yaşadıkları sonucuna ulaşılmıştır. Covid-19 servisinde görev yapan sağlık çalışanlarının \%3,6, idari birimlerde görev yapanların $\% 31,2$, acil servis ve ekibinde yer alanların $\% 9,1$, yoğun bakım ve ameliyathanede görev yapanların \%6,3 ve polikliniklerde görev yapanların \%49,8 ile düşük düzeyde duyarsızlaşma yaşadıkları sonucuna ulaşılmıştır. Bu sonuçlara göre araştırma hipotezi olarak ileri sürülen $\mathrm{H}_{2}$ hipotezi kabul edilmiştir. Araştırmaya katılan sağlık çalışanlarının haftalık çalışma ortamından memnuniyet durumu ile duyarsızlaşma arasında istatistiksel olarak anlamlı ilişki bulunmaktadır ( $\mathrm{p}<0.05)$. Çalışma ortamından memnun olan sağlık çalışanlarının \%32,2 oranında, çalışma ortamından memnun olmayanların ise, \%67,8 oranında yüksek duyarsızlaşma yaşadıkları sonucuna ulaşılmıştır. Çalışma ortamından memnun olanların \% 75,0 oranında orta düzeyde duyarsızlaşma yaşadıkları görülürken bu oran çalışma ortamından memnun olmayanlarda \%25,0 oranındadır. Çalışma ortamından memnun 88,9 olanların \%oranında düşük düzeyde duyarsızlaşma yaşadığı belirlenirken, çalışma ortamından memnun olmayanların oranı \%11,1'dir. Bu sonuçlara göre araştırma hipotezi olarak ileri sürülen $\mathrm{H}_{4}$ hipotezi kabul edilmiştir. Araştırmaya katılan sağlık çalışanlarının Covid-19 pandemisinin stres düzeyini arttırma durumu ile duyarsızlaşma arasında istatistiksel olarak anlamlı ilişki bulunmaktadır $(\mathrm{p}<0.05)$. Covid-19 pandemisinde stres düzeylerinin arttığını belirten sağlık çalışanlarının \%98,3 oranında, stres düzeylerinin artmadığını belirtenler ise, \%1,7 ile yüksek oranda duyarsızlaşma yaşamaktadırlar. Bu oran orta düzeyde de benzer aralıkta iken, stres düzeylerinin artığını belirtenler \%78,3 oranında, stres düzeylerinin artmadığını belirtenler ise, \%21,7 ile düşük duyarsızlaşmaya sahiptir. Bu sonuçlara göre araştırma hipotezi olarak ileri sürülen $\mathrm{H}_{5}$ hipotezi kabul edilmiştir.

Diğer taraftan Maslach Tükenmişlik Ölçeğinin duyarsılaşma düzeyine göre katılımcıların medeni durum, eğitim durumu, haftalık çalışma saati arasında istatistiksel olarak anlamlı bir fark saptanmamıştır $(\mathrm{p}>0,05)$. Bu sonuçlara göre araştırma hipotezi olarak ileri sürülen $\mathrm{H}_{3}$ hipotezi ret edilmiştir. 
Maslach Tükenmişlik Ölçeğinin kişisel başarı azalma hissi düzeyine göre araştırmaya katılan sağlık çalışanlarının bazı tanımlayıcı özelliklerinin dağılımı tablo 7'de sunulmuştur.

Tablo7: Maslach Tükenmişlik Ölçeğinin kişisel başarı azalma hissi düzeyine göre araştırmaya katılan sağlık çalışanlarının bazı tanımlayıcı özelliklerinin dağılımı

\begin{tabular}{|c|c|c|c|c|c|c|c|c|}
\hline & \multicolumn{6}{|c|}{ KİŞİSEL BAŞARI AZALMA HİSSİ } & \multirow[t]{3}{*}{$\mathrm{X}^{2}$} & \multirow[t]{3}{*}{$\mathrm{P}^{*}$} \\
\hline & \multicolumn{2}{|c|}{ Yüksek } & \multicolumn{2}{|c|}{ Orta } & \multicolumn{2}{|c|}{ Düşük } & & \\
\hline & $\mathrm{N}$ & $\%$ & $\mathrm{~N}$ & $\%$ & $\mathrm{~N}$ & $\%$ & & \\
\hline \multicolumn{9}{|l|}{ Cinsiyet } \\
\hline Kadın & 56 & 58,9 & 73 & 64,0 & 35 & 24,5 & 47.876 & .00 \\
\hline Erkek & 39 & 41,1 & 41 & 36,0 & 108 & 75,5 & & \\
\hline Toplam & 95 & 100,0 & 114 & 100,0 & 143 & 100,0 & & \\
\hline \multicolumn{9}{|l|}{ Yaş } \\
\hline 25 yaş ve altı & 18 & 18,9 & 22 & 19,3 & 6 & 4,2 & 45.700 & .00 \\
\hline $26-35$ & 42 & 44,2 & 65 & 57,0 & 49 & 34,3 & & \\
\hline $36-45$ & 27 & 28,4 & 18 & 15,8 & 70 & 49,0 & & \\
\hline 46 ve üzeri & 8 & 8,4 & 9 & 7,9 & 18 & 12,6 & & \\
\hline Toplam & 95 & 100,0 & 114 & 100,0 & 143 & 100,0 & & \\
\hline \multicolumn{9}{|c|}{ Medeni Durum } \\
\hline Evli & 58 & 61,1 & 74 & 64,9 & 125 & 87,4 & 25.741 & .00 \\
\hline Bekâr & 37 & 38,9 & 40 & 35,1 & 18 & 12,6 & & \\
\hline Toplam & 95 & 100,0 & 114 & 100,0 & 143 & 100,0 & & \\
\hline \multicolumn{9}{|c|}{ Eğitim durumu } \\
\hline Lise & 33 & 34,7 & 8 & 7,0 & 2 & 1,4 & 80.392 & .00 \\
\hline Ön lisans & 21 & 22,1 & 25 & 21,9 & 24 & 16,8 & & \\
\hline Lisans & 35 & 36,8 & 44 & 38,6 & 61 & 42,7 & & \\
\hline Lisansüstü & 6 & 6,3 & 37 & 32,5 & 56 & 39,2 & & \\
\hline Toplam & 95 & 100,0 & 114 & 100,0 & 143 & 100,0 & & \\
\hline \multicolumn{9}{|c|}{ Çalıştığınız birim } \\
\hline $\begin{array}{l}\text { Covid-19 } \\
\text { servisi }\end{array}$ & 5 & 5,3 & 13 & 11,4 & 4 & 2,8 & 125.888 & .00 \\
\hline İdari birimler & 63 & 66,3 & 19 & 16,7 & 15 & 10,5 & & \\
\hline $\begin{array}{l}\text { Acil servis ve } \\
\text { ekibi }\end{array}$ & 5 & 5,3 & 9 & 7,9 & 19 & 13,3 & & \\
\hline $\begin{array}{l}\text { Yoğun bakım- } \\
\text { ameliyathane }\end{array}$ & 5 & 5,3 & 20 & 17,5 & 8 & 5,6 & & \\
\hline Poliklinik & 17 & 17,9 & 53 & 46,5 & 97 & 67,8 & & \\
\hline Toplam & 95 & 100,0 & 114 & 100,0 & 143 & 100,0 & & \\
\hline \multicolumn{9}{|c|}{ Haftalık çalışma saati } \\
\hline 25 saat ve alt 1 & 27 & 28,4 & 23 & 20,2 & 7 & 4,9 & 53.384 & .00 \\
\hline $26-45$ saat & 31 & 32,6 & 19 & 16,7 & 16 & 11,2 & & \\
\hline $\begin{array}{l}46 \text { saat ve } \\
\text { üzeri }\end{array}$ & 37 & 38,9 & 72 & 63,2 & 120 & 83,9 & & \\
\hline Toplam & 95 & 100,0 & 114 & 100,0 & 143 & 100,0 & & \\
\hline \multicolumn{9}{|c|}{ Çalışma ortamından memnun musunuz? } \\
\hline Evet & 77 & 81,1 & 64 & 56,1 & 133 & 93,0 & 50.760 & .00 \\
\hline Hayır & 18 & 18,9 & 50 & 43,9 & 10 & 7,0 & & \\
\hline
\end{tabular}




\begin{tabular}{|c|c|c|c|c|c|c|c|c|}
\hline Toplam & 95 & 100,0 & 114 & 100,0 & 143 & 100,0 & & \\
\hline \multicolumn{9}{|c|}{ Covid-19 stres düzeyini arttırdı mı? } \\
\hline Evet & 86 & 90,5 & 105 & 92,1 & 102 & 71,3 & 24.579 & .00 \\
\hline Hayır & 9 & 9,5 & 9 & 7,9 & 41 & 28,7 & & \\
\hline Toplam & 95 & 100,0 & 114 & 100,0 & 143 & 100,0 & & \\
\hline
\end{tabular}

Tablo 7'de araştırmaya katılan sağlık çalışanlarının cinsiyet durumu ile kişisel başarı azalma hissi arasında istatistiksel olarak anlamlı ilişki bulunmaktadır $(\mathrm{p}<0.05)$. Yüksek kişisel başarı azalma hissi yaşayan katılımcıların yüzdeleri incelendiğinde kadınların \%58,9, erkeklerin \%41,1 yüksek kişisel başarı azalma hissi yaşadıkları görülmektedir. Orta düzey kişisel başarı azalma hissinde ise, kadınlar \%64,0 oranında iken erkeklerde bu oran \%36,0 oranındadır. Düşük kişisel başarı azalma hissi yaşayan katılımcılar \%75,5 ile erkeklerdir. Araştırmaya katılan sağlık çalışanlarının yaş durumu ile kişisel başarı azalma hissi arasında istatistiksel olarak anlamlı ilişki bulunmaktadır ( $\mathrm{p}<0.05$ ). 25 yaş ve altı grubunda \% 18,9, 26-35 yaş grubunda $\% 44,2,36-45$ yaş grubunda $\% 28,4$ ve 46 yaş ve üzeri grupta $\% 8,4$ oranında yüksek düzeyde kişisel başarı azalma hissi yaşandığı sonucuna ulaşılmıştır. 25 yaş ve altı grubunda $\% 19,3,26-35$ yaş grubunda $\% 57,0,36-45$ yaş grubunda $\% 15,8$ ve 46 yaş ve üzeri grupta \%7,9 oranında orta düzeyde kişisel başarı azalma hissi yaşandığı sonucuna ulaşılmıştır. 25 yaş ve altı grubunda \%4,2, 26-35 yaş grubunda \%34,3, 36-45 yaş grubunda $\% 49,0$ ve 46 yaş ve üzeri grupta \%12,6 oranında düşük düzeyde kişisel başarı azalma hissi yaşandığı sonucuna ulaşılmıştır. Araştırmaya katılan sağlık çalışanlarının medeni durumu ile kişisel başarı azalma hissi arasında istatistiksel olarak anlamlı ilişki bulunmaktadır $(\mathrm{p}<0.05)$. Yüksek kişisel başarı azalma hissi yaşayan katılımcıların yüzdeleri incelendiğinde evli katılımcıların \%61,1, bekâr katılımcıların \%38,9 yüksek kişisel başarı azalma hissi yaşadıkları görülmektedir. Orta düzey kişisel başarı azalma hissinde ise evli katılımcıların \%64,9, bekâr katılımcıların \%35,1 oranında kişisel başarı azalma hissi yaşadıkları görülürken, düşük kişisel başarı azalma hissi yaşayan evli katılımcıların \%87,4, bekâr katılımcıların \%12,6 kişisel başarı azalma hissi yaşadıkları belirlenmiştir. Araştırmaya katılan sağlık çalışanlarının eğitim durumu ile kişisel başarı azalma hissi arasında istatistiksel olarak anlamlı ilişki bulunmaktadır $(\mathrm{p}<0.05)$. Lise mezunu katılımcıların \%34,7, ön lisans mezunlarının \%22,1, lisans mezunlarının \%36,8, lisansüstü mezunların \%6,3 oranında yüksek kişisel başarı azalma hissi yaşadığı sonucuna ulaşılmıştır. Lise mezunu katılımcıların \%7,0, ön lisans mezunlarının \%21,9, lisans mezunlarının \%38,6, lisansüstü mezunların \%32,5 oranında orta kişisel başarı azalma hissi yaşadığı sonucuna ulaşılmıştır. Lise mezunu katılımcıların \%1,4, ön lisans mezunlarının \%16,8, lisans 
mezunlarının \%42,7, lisansüstü mezunların \%39,2 oranında düşük kişisel başarı azalma hissi yaşadığı sonucuna ulaşılmıştır. Bu sonuçlara göre araştırma hipotezi olarak ileri sürülen H1 hipotezi kabul edilmiştir. Araştırmaya katılan sağlık çalışanlarının çalıştığı birim ile kişisel başarı azalma hissi arasında istatistiksel olarak anlamlı ilişki bulunmaktadır $(\mathrm{p}<0.05)$. Covid19 servisinde görev yapan sağlık çalışanlarının \%5,3, idari birimlerde görev yapanların \%66,3, acil servis ve ekibinde yer alanların \%5,3, yoğun bakım ve ameliyathanede görev yapanların $\% 5,3$ ve polikliniklerde görev yapanların \%17,9 ile yüksek düzeyde kişisel başarı azalma hissi yaşadıkları sonucuna ulaşılmıştır. Diğer yandan covid-19 servisinde görev yapan sağlık çalışanlarının \%11,4, idari birimlerde görev yapanların \%16,7, acil servis ve ekibinde yer alanların \%7,9, yoğun bakım ve ameliyathanede görev yapanların \%17,5 ve polikliniklerde görev yapanların \%46,5 ile orta düzeyde kişisel başarı azalma hissi yaşadıkları sonucuna ulaşılmıştır. Covid-19 servisinde görev yapan sağlık çalışanlarının \%2,8, idari birimlerde görev yapanların \%10,5, acil servis ve ekibinde yer alanların \%13,3, yoğun bakım ve ameliyathanede görev yapanların \%5,6 ve polikliniklerde görev yapanların \%67,8 ile düşük düzeyde kişisel başarı azalma hissi yaşadıkları sonucuna ulaşılmıştır. Bu sonuçlara göre araştırma hipotezi olarak ileri sürülen $\mathrm{H}_{2}$ hipotezi kabul edilmiştir.Araştırmaya katılan sağlık çalışanlarının haftalık çalışma saatleri ile kişisel başarı azalma hissi arasında istatistiksel olarak anlamlı ilişki bulunmaktadır ( $\mathrm{p}<0.05$ ). Katılımcılardan 25 saat ve altı çalışanların \%28,4, 26-45 saat arası çalışanların \%32,6, 46 saat ve üzeri çalışanların \%38,9 oranında yüksek düzeyde kişisel başarı azalma hissi yaşadığı sonucuna ulaşılmıştır. Katılımcılardan 25 saat ve altı çalışanların \%20,2, 26-45 saat arası çalışanların \%16,7, 46 saat ve üzeri çalışanların \%63,2 oranında orta düzeyde kişisel başarı azalma hissi yaşadığı sonucuna ulaşılmıştır. Katılımcılardan 25 saat ve altı çalışanların \%4,9, 26-45 saat arası çalışanların \%11,2, 46 saat ve üzeri çalışanların \%83,9 oranında düşük düzeyde kişisel başarı azalma hissi yaşadı ğı sonucuna ulaşılmıştır. Bu sonuçlara göre araştırma hipotezi olarak ileri sürülen $\mathrm{H}_{3}$ hipotezi kabul edilmiştir. Araştırmaya katılan sağlık çalışanlarının haftalık çalışma ortamından memnuniyet durumu ile kişisel başarı azalma hissi arasında istatistiksel olarak anlamlı ilişki bulunmaktadır $(\mathrm{p}<0.05)$. Yüksek kişisel başarı azalma hissi yaşayan katılımcıların yüzdeleri incelendiğinde çalışma ortamından memnun olanların \%81,1, çalışma ortamından memnun olmayanların \%18,9 yüksek kişisel başarı azalma hissi yaşadıkları görülmektedir. Orta düzey kişisel başarı azalma hissinde ise büyük oranda farklılık görülmezken, çalışma ortamından memnun olanların \%93,0, çalışma ortamından memnun olmayanların $\% 7,0$ oranında düşük kişisel başarı azalma hissi yaşadıkları belirlenmiştir. $\mathrm{Bu}$ sonuçlara göre araştırma hipotezi olarak ileri sürülen $\mathrm{H}_{4}$ hipotezi kabul edilmiştir.Araştırmaya katılan sağlık çalışanlarının Covid-19 pandemisinin stres düzeyini 
arttırma durumu ile kişisel başarı azalma hissi arasında istatistiksel olarak anlamlı ilişki bulunmaktadır ( $\mathrm{p}<0.05)$. Yüksek kişisel başarı azalma hissi yaşayan katılımcıların yüzdeleri incelendiğinde Covid-19 pandemisinin stres seviyelerini arttırdığını söyleyenlerin \%090,5, stres seviyelerini etkilemediğini söyleyenlerin ise, \%9,5 yüksek kişisel başarı azalma hissi yaşadıkları görülmektedir. Orta düzeyde ise, stres seviyelerinde artış olanların \%92,1, stres seviyelerinde artış olmayanların ise, \%7,9 kişisel başarı azalma hissi yaşadıkları görülmüştür. Stres seviyelerinde artış olanların \%71,3, stres seviyelerinde artış olmayanların ise, \%28,7 oranında düşük seviyede kişisel başarı azalma hissi yaşadıkları sonucuna ulaşılmıştır. $\mathrm{Bu}$ sonuçlara göre araştırma hipotezi olarak ileri sürülen $\mathrm{H}_{5}$ hipotezi kabul edilmiştir.

\section{SONUÇ VE ÖNERILER}

Sağlık çalışanlarında tükenmişlik konusu günümüz şartlarında giderek daha da önem kazanmaya başlamıştır. Sağlık çalışanlarının yaşamış oldukları tükenmişlik durumu ise, düşük hasta memnuniyeti, yapılabilecek tıbbi hatalarda artış, mesleki tatmin düzeylerinde düşüklük gibi sonuçları ortaya çıkartabilmektedir. Tükenmişlik sonucu ortaya çıkabilecek bu olumsuzlukların önlenmesi sağlık sistemi ve sağlık çalışanları için önemli bir durumdur. $\mathrm{Bu}$ çalışmada sağlık çalışanlarının Covid-19 pandemisi sırasında tükenmişlik düzeyleri Maslach Tükenmişlik Ölçeği ile değerlendirilmiştir. Yapılan çalışma sonucunda, araştırmaya katılan 352 sağlık çalışanının \%53,4'ünün erkek, \%73'ünün evli, \%44,3'ünün 26-35 yaş aralığında, \%65,6'sının çocuk sahibi olduğu ve \%39,8'inin lisans eğitimi aldığı görülmüştür. Katılımcıların \%67,3'ü düşük duygusal tükenme, \%71,9'u düşük duyarsızlaşma düzeyine ve \%40,6'sı düşük kişisel başarı azalma hissine sahiptir. Lin ve diğerleri (2019) acil tıp asistanlarının \%46,1'inin yüksek duygusal tükenme, \%72,5'inin yüksek duyarsızlaşma ve \%30,6'sının düşük kişisel başarı azalma hissine sahip olduğu sonucuna ulaşmıştır. Alyamani ve diğerleri (2018) de Suudi Arabistan'da asistan hekimlerin \%12,5'inin yüksek duygusal tükenmeye, \%51,0'inin yüksek duyarsızlaşmaya ve \%31,5'inin düşük kişisel başarı hissine sahip olduğunu belirtmiştir.

Çalışmaya katılan sağlık çalışanlarının cinsiyetleri ile tükenmişlik durumları arasındaki ilişkiye bakıldığında; kadın sağlık çalışanlarının erkek çalışanlara oranla duygusal tükenme, duyarsızlaşma puanlarının yüksek olduğu; kişisel başarı azalma hissi durumlarının ise orta düzeyde olduğu sonucuna ulaşılmıştır. Bu sonuçlara göre $\mathrm{H}_{1}$ hipotezi tüm alt boyutlar için kabul edilmiştir. Elmore ve diğerlerinin (2016) genel cerrahi asistanlarını dâhil ettikleri çalışmada kadın hekimlerin duygusal tükenme ve duyarsızlaşma açısından tükenmişlik düzeylerinin 
yüksek olduğu saptanmıştır. Bu sonuç yapılan çalışma sonuçları ile benzerlik göstermektedir. Kişisel başarı azalma hissi açısından ise anlamlı farklılık bulunamamıştır.

Katılımcıların yaş grupları ile tükenmişlik düzeyleri arasındaki ilişkiye bakıldığında; duygusal tükenme, duyarsızlaşma ve kişisel başarı azalma hissi arasında istatistiksel olarak anlamlı fark elde edilmiştir. Bu sonuçlara göre $\mathrm{H}_{1}$ hipotezi tüm alt boyutlar için kabul edilmiştir. Perlman ve Hartman (1982) yaptıkları çalışmada yaş ve tükenmişlik arasında olumsuz bir ilişkiden söz etmektedirler. Yaş arttıkça tükenmişlikle karşılaşma riskinin düştüğü sonucuna ulaşmışlardır. Lee ve Ashforth (1993) ise yaptıkları çalışmada yaş ile tükenmişlik arasında negatif bir ilişki olduğunu belirtmiştir. Genç ve deneyimsiz çalışanların, işin gerekleri ile baş etmeyi henüz yeterince bilmedikleri için duygusal tükenmeye karşı dayanıksız olabildiklerini belirtmişlerdir.

Katılımcıların medeni durumları ile tükenmişlik düzeyleri arasındaki ilişkiye bakıldığında; duygusal tükenme ve kişisel başarı azalma hissi arasında istatistiksel olarak anlamlı fark elde edilirken, duyarsızlık puanları açısından anlamlı bir fark elde edilmemiştir. $\mathrm{Bu}$ sonuçlara göre $\mathrm{H}_{1}$ hipotezi duygusal tükenme ve kişisel başarı alt boyu için kabul edilirken, duyarsızlık alt boyutu açısından red edilmiştir. Erol ve diğerlerinin (2007) asistan hekimlere yapmış oldukları çalışmada ise, medeni durum ile tükenmişlik alt ölçekleri arasında anlamlı bir fark saptanamamıştır.

Katılımcıların eğitim durumları ile tükenmişlik düzeyleri arasındaki ilişkiye bakıldığında; kişisel başarı azalma hissi durumu ile eğitim durumu arasında anlamlı fark elde edilirken, duygusal tükenme ve duyarsızlaşma ile eğitim durumu arasında anlamlı bir fark elde edilmemiştir. $\mathrm{Bu}$ sonuçlara göre $\mathrm{H}_{1}$ hipotezi kişisel başarı azalma hissi alt boyutu için kabul edilirken, duygusal tükenme ve duyarsızlaşma alt boyutları için ret edilmiştir. Güneşen ve Üstün (2010) tarafından yapılan çalışmada eğitim düzeyi düşük olanların tükenmişlik yönünden riskli gruplar içerisinde yer aldığı sonucuna ulaşmışlardır. Tekin (2009) yapmış olduğu çalışmada eğitim durumuna göre tükenmişlik alt boyutları arasında anlamlı bir fark saptanmamasına rağmen, ön lisans mezunu olanlarda "duygusal tükenme”, yüksek lisans mezunu olanlarda "kişisel başarısızlık" ve lisans mezunu olanlarda ise "duyarsızlaşma" ortalamalarının yüksek olduğu belirlenmiştir.

Katılımcıların çalıştıkları birim ile tükenmişlik düzeyleri arasındaki ilişkiye bakıldığında; duygusal tükenme, duyarsızlaşma ve kişisel başarı azalma hissi arasında istatistiksel olarak anlamlı fark elde edilmiştir. Bu sonuçlara göre geliştirilen $\mathrm{H}_{2}$ hipotezi kabul edilmiştir. Metin ve Özer (2004) yaptıkları çalışmada sağlık personelinin çalıştığı bölüm ile 
duygusal tükenme arasında anlamlı farklılık olduğu ve bu farkın acil, yoğun bakım ve cerrahi branşlarda çalışmanın etkisi olduğu sonucuna ulaşmışlardır. Barutçu ve Serinkan (2008) yaptıkları çalışmada yoğun bakım ve acil birimlerde çalışanlarda duygusal tükenme ve duyarsızlaşmanın yüksek olduğu sonucuna ulaşmışlardır. Sonuçlar yapılan çalışmayı destekler niteliktedir.

Katılımcıların haftalık çalışma saatleri ile tükenmişlik düzeyleri arasındaki ilişkiye bakıldığında; duygusal tükenme ve kişisel başarı azalma hissi arasında anlamlı fark elde edilirken, duyarsızlaşma açısından anlamlı bir fark saptanmamıştır. Bu sonuçlara göre geliştirilen $\mathrm{H}_{3}$ hipotezi duygusal tükenme ve kişisel başarı azalma hissi alt boyutlarında kabul edilirken, duyarsızlaşma alt boyutunda ret edilmiştir. Üstün (1995) yapmış olduğu çalışmada gece, gündüz çalışan hemşirelerin duygusal tükenme ve duyarsızlaşma boyutlarının daha yüksek olduğunu belirlemiştir. Kavla (1998) yapmış olduğu çalışmada, nöbet tutan hemşirelerin duyarsızlaşma düzeylerinin, nöbet tutmayan hemşirelerin ise kişisel başarı azalma hissi düzeylerinin daha yüksek olduğunu, nöbet tutma durumuna göre hemşirelerin kişisel başarı azalma hissi düzeylerinde anlamlı bir farklılık olduğunu saptamıştır.

Çalışma ortamının memnuniyetsizlik yaratacak bir ortam olması önemli risk faktörleri arasındadır. Katılımcıların çalışma ortamlarından memnun olma durumları ile tükenmişlik arasındaki ilişkiye bakıldığında; duygusal tükenme, duyarsızlaşma ve kişisel başarı azalma hissi arasında istatistiksel olarak anlamlı fark elde edilmiştir. Bu sonuçlara göre $\mathrm{H}_{4}$ hipotezi tüm alt boyutlar için kabul edilmiştir. Karadayı (2020) yapmış olduğu çalışmada çalışma ile benzer şekilde tüm alt ölçeklerde yüksek oranda tükenmişlik görüldüğü sonucuna ulaşılmıştır.

Katılımcıların Covid-19 pandemisinin stres düzeyini arttırma durumu ile tükenmişlik arasındaki ilişkiye bakıldığında; duygusal tükenme, duyarsızlaşma ve kişisel başarı azalma hissi arasında istatistiksel olarak anlamlı fark elde edilmiştir. $\mathrm{Bu}$ sonuçlara göre geliştirilen $\mathrm{H}_{5}$ hipotezi tüm alt boyutlar için kabul edilmiştir. Armutçuk (2010) yapmış olduğu çalışmada, hekim dışı sağlık personellerinin işe bağlı stres düzeyleri ile duygusal tükenme puanı arasında pozitif yönlü anlamlı bir fark elde edilirken, kişisel başarı azalma hissi puanı arasında negatif yönlü anlamlı bir fark saptamıştır.

Tükenmişlik durumunun sağlık çalışanları gibi insanlarla sürekli ilişski içerisinde olduğu meslek gruplarında sık karşılaşıldığı bilinmektedir. Sağlık çalışanlarının tükenmişlik durumlarındaki artış hastalar açısından da olumsuz sonuçlara sebep olabileceği için önemli bir sorundur. Özellikle devam eden Covid-19 süreci sebebiyle artan tükenmişlik durumunun önüne geçilebilmesi adına sağlık çalışanlarını motive edici düzenlemeler yapılması gerekmektedir. 
Tükenmişlik seviyelerinin azalabilmesi için sağlık çalışanlarının güven içinde çalışma duygusunda artış sağlanması, gelir durumlarında ki iyileştirmeler, görev dağılımlarının eşit yapılması, mobbingin önlenmesi gibi çalışmalar yapılması önerilmektedir.

Sürgevil (2006), yapmış olduğu çalışmada tükenmişliğin bireyin çalışma ortamıyla etkileşim içinde olmasının bir sonucu olması sebebiyle örgütsel koşulları iyileştirmek için alınabilecek tüm önlemlerin gerekli olduğunu ve tükenmişliği önleyebileceğini belirtmiştir. Sürgevil (2006)'e göre bu önlemler stresli iş saatlerini düzenlemek ve azaltmak, kurum içi eğitim olanaklarını artırmak, hizmet talep eden kişilerle karşılaşılabilecek problemleri azaltacak önlemler almak, çalışma koşullarında iyileştirmeler yapmak, çalışanların kararlara katılımını artırmak, çalışanların yaşadığı monotonluğu azaltmak, çalışanın kurum ilgili hedef ve beklentilerinde gerçekçi olmalarını sağlamak, ödül sistemleri geliştirmek, başarıları takdir etmek, tükenmişliği önlemeye yönelik eğitimler ve seminerler düzenlemek, çalışma koşullarında çevre düzenlemeleri yapmak, etkin performans değerlendirme sistemleri oluşturmak gibi uygulamalar tükenmişliği önlemede sağlık kurumlarının alabileceği önlemler olabilir.

Sonuç olarak sağlık çalışanlarının yaşadığı tükenmişlik, tıbbi hataların artmasına ve hasta memnuniyetinin azalmasına sebep olabilmektedir. Ayrıca tükenmişlik yaşayan sağlık çalışanları, özel yaşamlarında da depresyon riskleri artış gösterebilmekte ve sosyal ilişkilerinde bozulmalar da yaşayabilmektedirler. (Barnett, 2017 s. 1035, Khasne , Dhakulkar, Mahajan , \& Kulkarni, 2020 s. 669). Tükenmişlik sendromunun sağlık çalışanları gibi yüz yüze iletişimin güçlü olduğu meslek gruplarında sık karşılaşılan bir durum olduğu bilinmektedir.Tükenmişlik sendromu sadece sağlık çalışanlarını değil hizmet talep edenleri de olumsuz etkileyen bir durumdur. Bu sebeple yaygın olan bu problemin nedenlerinin tespit edilip çözümler üretilmesi gerekmektedir. Sağlık kurumlarının sağlık çalışanlarının tükenmişlik düzeylerini azaltmaya yönelik motivasyonu arttırıcı düzenlemeler yapmaları önerilmektedir. Sağlık çalışanlarının pandemi döneminde maddi ve manevi olarak desteklenmesi tükenmişlik düzeylerini azaltmada önemli rol oynayacağı düşünülmektedir. 


\section{KAYNAKÇA}

Alsulimani , L. K., Farhat , A. M., Borah, R. A., AlKhalifah, C. A., Alyaseen, S. M., Alghamdi, S. M., \& Bajnaid , M. J. (2021). Health care worker burnout during the COVID-19 pandemic: A crosssectional survey study in Saudi Arabia. Suudi Med Journal, 306-314.

Alyamani, A., Alyamani, L., Altheneyan, F., Aldhali, S., Albaker, K., Alshaalan, A., . . Alyamani, A. (2018). Prevalence of Burnout among Residents at King Abdulaziz Medical City in Riyadh, Saudi Arabia. International Journal of Medical Research \& Health Sciences , 37-40.

Arslan, G., Yıldırım, M., Tanhan, A., Buluş, M., \& Allen, K.-A. (2020). Coronavirus Stress, OptimismPessimism, Psychological Inflexibility, and Psychological Health: Psychometric Properties of the Coronavirus Stress Measure. International Journal of Mental Health and Addiction .

Artmutçuk, A. K. (2010). Denizli Devlet Hastanesinde Çalışmakta Olan Hekim Dışı Sağglık Personelinde Tükenmişlik Sendromu Ve İlişkili Değişkenler. Pamukkale Üniversitesi, Sağlık Bilimleri Enstitüsü, Halk Sağllğg Anabilim Dall, Yüksek Lisans Tezi.

Baptista, S., Teixeira, A., Castro, L., Cunha, M., Serrão, C., Rodrigues, A., \& Duarte, I. (2021). Physician Burnout in Primary Care during the COVID-19 Pandemic: A Cross-Sectional Study in Portugal. Journal of Primary Care \& Community Health.

Barnett, K. (2017). In Pursuit of the Fourth Aim in Health Care: The Joy of Practice. The Medical Clinics North America, 1031-1040.

Barutçu, E., \& Serinkan, C. (2008). Günümüzün Önemli Sorunlarından Biri Olarak Tükenmişlik Sendromu ve Denizli'de Yapılan Bir Araştırma. Ege Akademik Bakış, 541-561.

Düzyürek, S., \& Ünlüoğlu, G. (1992). Hekimde Tükenmişlik (Burnout) Sendromu. Psikiyatri Bülteni, 108-112.

Elmore, L. C., Jeffe, D. B., Jin, L., Awad, M. M., \& Turnbull, I. R. (2016). National Survey of Burnout among US General Surgery Residents. Journal of the American College of Surgeons, 440-451.

Ergin, C. (1992). Doktor ve Hemşirelerde Tükenmişllik ve Maslach Tükenmişllik Ölçeği'nin Uyarlanması. 7.Ulusal Psikoloji Kongresi Bilimsel Çalışmaları, 143-154.

Erol, A., Sarıçiçek, A., \& Gülseren, Ş. (2007). Asistan hekimlerde tükenmişlik: İş doyumu ve depresyonla ilişkisi. Anadolu Psikiyatri Dergisi, 241-247.

Fawzy, F., Fawzy, N., \& Pasnau , R. (1991). Burnout in The Health Professionals. Handbook of Studies on General Hospital Psychiatry, 119.

Ge, Z.-y., Yang , L.-m., Xia, J.-j., Fu, X.-h., \& Zhang, Y.-z. (2020). Possible aerosol transmission of COVID-19 and special precautions in dentistry. In Journal of Zhejiang University: Science B, 361-368. 
Jalili, M., Niroomand , M., Hadavand, F., Zeinali , K., \& Fotouhi, A. (2021). Burnout among healthcare professionals during COVID-19 pandemic: a cross-sectional study. Int Arch Occup Environ Health, 1-8.

Kaçmaz, N. (2005). Tükenmişlik (Burnout) Sendromu. İstanbul Tıp Fakültesi Dergisi, 29-32.

Karadayı, B. S. (2020). COVID-19 Pandemisinin Anesteziyoloji ve Reanimasyon Uzmanları ve Araştırma Görevlilerindeki Tükenmişlik Üzerine Etkisi. Çukurova Üniversitesi, Tip Fakültesi, Anestezi ve Reanimasyon Anabilim Dall. Adana.

Kavla, İ. (1998). Hemşirelerde İş Doyumu İle Tükenmişlik İlişkisi. Dokuz Eylül Üniversitesi, Sağllk Bilimleri Enstitüsü, Yüksek Lisans Tezi.

Khasne, R. W., Dhakulkar, B. S., Mahajan, H. C., \& Kulkarni, A. P. (2020). Burnout among Healthcare Workers during COVID-19 Pandemic in India: Results of a Questionnaire-based Survey. Indian J Crit Care Med, 664-671.

Lasalvia, A., Amaddeo, F., Porru , S., Carta , A., Tardivo, S., Bovo, C., . . Bonetto, C. (2021). Levels of burn-out among healthcare workers during the COVID-19 pandemic and their associated factors: a cross-sectional study in a tertiary hospital of a highly burdened area of north-east Italy . BMJ Open.

Lee, R. T., \& Ashforth, B. E. (1993). A further examination of managerial burnout: Toward an integrated model. Journal of Organizational Behavior, 3-20.

Leskovic, L., Erjavec, K., Leskovar, R., \& Vukovič, G. (2020). Burnout and job satisfaction of healthcare workers in Slovenian nursing homes in rural areas during the COVID-19 pandemic. Ann Agric Environ Med, 664-671.

Lin, M., Battaglioli, N., Melamed , M., Mott , S. E., Chung, A. S., \& Robinson , D. W. (2019). High Prevalence of Burnout Among US Emergency Medicine Residents: Results From the 2017 National Emergency Medicine Wellness Survey. Ann Emerg Med, 682-690.

Maslach , C., \& Leiter , M. P. (2016). Understanding the burnout experience: recent research and its implications for psychiatry. World Psychiatry, 103-111.

Maunder, R. G., Heeney, N. D., Öpücük, A., Hunter, J. J., Jeffs , L. P., Ginty, L., . . Wiesenfeld , L. A. (2021). Psychological impact of the COVID-19 pandemic on hospital workers over time: Relationship to occupational role, living with children and elders, and modifiable factors. Gen Hosp Psychiatry, 88-94.

Metin, Ö., \& Özer, F. G. (2004). Hemşirelerin Tükenmişlik Düzeylerinin Belirlenmesi . III. Uluslararası Hemşirelik Öğrencileri Kongresi, Edirne. 
Mukherjee, S., Tennant, A., \& Beresford, B. (2019). Measuring Burnout in Pediatric Oncology Staff: Should We Be Using the Maslach Burnout Inventory? Journal of Pediatric Oncology Nursing, 51-64.

Nesanır, N., Bahadır, A., Karcıŏlu, Ö., \& Korur Fincancı, Ş. (2021). Türkiye'de Sağllk Çalışanı Ölümlerinin Anlattı̆̆ı. Türk Tabipler Birliği.

Nishimura, Y., Miyoshi, T., Hagiya, H., Kosaki, Y., \& Otsuka, F. (2021). Burnout of Healthcare Workers amid the COVID-19 Pandemic: A Japanese Cross-Sectional Survey. Int J Environ Res Public Health.

Pantenburg , B., Luppa, M., König, H.-H., \& Riedel-Heller, S. G. (2016). Burnout among young physicians and its association with physicians' wishes to leave: results of a survey in Saxony, Germany. J Occup Med Toxicol.

Partlak Günüşen, N., \& Üstün, B. (2010). Türkiye'de İkinci Basamak Sağlık Hizmetlerinde Çalışan Hemşire ve Hekimlerde Tükenmişlik: Literatür İncelemesi. Dokuz Eylül Üniversitesi Hemşirelik Yüksekokulu Elektronik Dergisi , 40-51.

Perlman, B., \& Hartman, A. E. (1982). Burnout: Summary and future research. Human Relations, 283305.

Shanafelt, T. D., Balch, C. M., Bechamps, G., Russell, T., Dyrbye, L., Satele, D., . . Freischlag, J. (2010). Burnout and Medical Errors Among American Surgeons. Annals of Surgery, 995-1000.

Suñer-Soler, R., Grau-Martín, A., Flichtentrei, D., Prats, M., Braga, F., Font-Mayolas, S., \& Gras, M. (2014). The consequences of burnout syndrome among healthcare professionals in Spain and Spanish speaking Latin American countries. Burnout Research, 82-89.

Sürgevil Dalkılıç, O. (2006). Çalı̧̧ma Hayatında Tükenmişlik Sendromu Tükenmiş̧likle Mücadele Teknikleri. Ankara: Nobel Yayınları.

Tekin, A. (2009). Yönetici hemşirelerin tükenmişlik düzeylerinin belirlenmesi. Haliç Üniversitesi Yayınlarl,Yüksek Lisans Tezi,.

Üstün, B. (1995). Hemşirelerin Atılganlık ve Tükenmişlik Düzeyleri. Hacettepe Üniversitesi Sağlık Bilimleri Enstitüsü, Doktora Tezi.

Yazıcıoğlu, Y., \& Erdoğan, S. (2004). SPSS Uygulamalı Bilimsel Araştırma Yöntemleri. Ankara: Detay Yayınc1lik.

Yumru, M. (2020). COVID-19 ve Sağlık Çalışanlarında Tükenmişlik. Klinik Psikiyatri Dergisi, 5-6.

https://covid19.who.int/, (Erişim Tarihi: 07.08.2021)

https://covid19.saglik.gov.tr/ , (Erişim Tarihi: 05.08.2021) 